\title{
Development Aid and Export Resilience in Developing Countries: A Reference to Aid for Trade
}

\author{
Author: Sèna Kimm GNANGNON ${ }^{1}$
}

Manuscript date: June 2021

\author{
Affiliation: World Trade Organization \\ Postal Address: Rue de Lausanne 154, CH-1211 Geneva 21, Switzerland. \\ E-mail: kgnangnon@yahoo.fr
}

\begin{abstract}
The COVID-19 pandemic, like previous major crises, such as the 2008 financial crisis, has had a severe negative impact on international trade flows. International institutions are now exploring ways to help their member states recover from the health crisis, and foster the resilience of their economies to future crises. As far as trade is concerned, institutions that deal primarily with trade matters are making effort to help their member states foster the resilience of their trade performance to future shocks. In this context, the World Trade Organization (WTO), which is the only international organization that deals with the global rules of trade between nations, has organized a series of events since the onset of the COVID-19 pandemic. It has now planned to hold in September 2021 the 2021 WTO Public Forum whose theme is "Trade Beyond COVID19: Building Resilience". The present paper aims to contribute to this debate by examining the effect of development aid, i.e., the so-called official development aid, in particular its Aid for Trade (AfT) component, on export resilience. The resilience of exports refers to the capacity of countries' aggregate exports to resist to shocks, whether environmental or external shocks. The core argument of the analysis is that development aid would affect export resilience through its effect on productive capacities. The analysis covers 93 developing countries over the period 2002-2018. The findings indicate that total development aid flows, including both AfT flows and NonAfT flows exert a positive effect on export resilience. Among AfT components, AfT for productive capacities appears to exert a higher positive effect on export resilience than AfT for economic infrastructure and AfT for trade policy and regulation. In addition, development aid (whatever the aid variable considered) exerts the highest positive effect on export resilience in countries (such as Least developed countries - LDCs) that have the lowest level of productive capacities. These findings highlight the need for donor-countries to supply higher development aid flows, in particular AfT flows to countries such as LDCs that have low levels of productive capacities.
\end{abstract}

Keywords: Development Aid; Productive capacities; Export resilience; Developing countries. JEL Classification: D24; F35; O1.

${ }^{1}$ World Trade Organization (WTO), Geneva, Switzerland. E-mail for correspondence: kgnangnon@yahoo.fr 


\section{DISCLAIMER}

This is a working paper, which represents the personal opinions of individual staff members and is not meant to represent the position or opinions of the WTO or its Members, nor the official position of any staff members. Any errors or omissions are the fault of the author. The author declares no competing interests.

\section{Introduction}

The COVID-19 pandemic, which is the second major crisis faced by the world after the 2008 financial crisis, has revived the interest of the international community in finding ways (e.g., policies) and means to strengthen resilience of economies to future shocks. The adverse effects of the COVID-19 health crisis on international trade flows, in particular on exports (e.g., Barlow et al., 2021; Chiah and Zhong, 2020; Hayakawa and Mukunoki, 2021; Li and Lin, 2021) highlight the need for exploring factors that are essential for fostering the resilience of countries' trade performance, notably their export performance to future shocks. Specially, national policymakers, notably in developing countries, are contemplating policies that could be deployed to recover from the COVID-19 health crisis, including after stemming the spread of the coronavirus. To help them in this challenging undertaking, including to inform policymakers' decisions, researchers and international institutions have been exploring, within their respective areas of expertise how to further help their member-states recover from the current COVID-19 pandemic and build resilient economies to future shocks (e.g., Bacchetta et al., 2021; Barkas et al. 2020; Davies et al., 2021; Evenett et al., 2020; OECD, 2020, 2021; IMF, 2021; Wu and Khazin, 2020).

In the field of international trade, several international organizations have been hardly working to help their respective member states face the challenges brought about by the COVID19 pandemic. Let us say a few words on how these organizations have been helping their respective member states navigate through the pandemic, and prepare for future crises. This would provide a first insight on how these organizations were struggling to ensure that their member-countries' trade, including exports be resilience to the COVID-19 health crisis.

Even though the World Bank is a financial development institution, and not a pure international trade institution, the promotion of trade is an important component of its portfolio. Through its research and policy analysis, as well as projects financing, the World Bank "helps countries improve their access to world markets and enhance their participation in the global trading system ${ }^{2}$." It has developed a website ${ }^{3}$ dedicated to its activities (specifically on the trade area) to help its members states use trade policies to respond to the COVID-19 outbreak.

The main objective of the International Trade Centre $\left(\right.$ ITC $\left.^{4}\right)$ is to ensure that trade is happening on the ground. To that effect, it works with policymakers, business support organizations and the business community to improve small firms' competitiveness, including through the implementation of technical assistance programmes for countries and entrepreneurs. The ITC has recently contributed to a global survey to assess the effects of the COVID-19 crisis on Micro, Small and Medium Enterprises (MSMEs), with a view to targeting support to the most

${ }^{2}$ See information online at: https://www.worldbank.org/en/topic/trade/overview

${ }^{3}$ The ITC is a joint agency of the United Nations and the World Trade Organization (WTO). See information on this institution online at https://www.worldbank.org/en/topic/trade/coronavirus

${ }^{4}$ Details on the activities of the ITC could be found online at: https://www.intracen.org/ 
relevant areas, and helping to build supply chains that are more resilient to shocks (see Antoniak et al., 2021).

The United Nations Conference on Trade and Development (UNCTAD) builds on its longstanding experience on research and evidence-based policy analysis on international trade, to provide advice and recommendations to its member countries on means and policies that can help mitigate the fallouts of the COVID-19 pandemic, and build resilience to future shocks ${ }^{5}$. The UNCTAD has developed and launched in February ${ }^{6} 2021$ a comprehensive index of productive capacities, with a view to helping researchers assess countries' performance in terms of productive capacities, and inform policymaking decision (UNCTAD, 2020). According to UNCTAD (2006, p61), 'productive capacities' refers to "the productive resources, entrepreneurial capabilities and production linkages which together determine the capacity of a country to produce goods and services, and enable it to grow and develop". This indicator of productive capacities has been constructed on the ground that enhancing productive capacities, particularly in developing countries and the Least developing countries $\left(\mathrm{LDCs}^{\top}\right)$ among them, would help build economic resilience to future shocks, and concurrently promote economic growth and sustainable development. Some papers have used this indicator of productive capacities to provide empirical support to the international policy discourse that enhancing productive capacities in developing countries, and particularly LDCs contribute to improving economies complexity (Gnangnon, 2021a), promoting economic growth and reducing output volatility (Gnangnon, 2021b), and building countries' resilience to shocks (Gnangnon, 2021c). In addition, Gnangnon (2021d) has uncovered empirically that development aid, in particular Aid for Trade flows play a strong role in building productive capacities in developing countries, including LDCs.

The World Trade Organization (WTO) is the only international institution in the world that deals with the global rules governing trade between nations. In the wake of COVID-19 pandemic, the W'TO has undertaken various activities to help its Members countries respond to the COVID19 pandemic. It has developed a dedicated website ${ }^{8}$, which provides detailed information on the impact of the pandemic on global trade. The website lists a series of reports by the WTO Secretariat on the 'COVID-19 pandemic and world trade'. Some recent working papers by the WTO Secretariat also contribute to better understanding how the WTO (including its Members countries) have been tackling the COVID-19 pandemic (e.g., Bacchetta et al. 2021; Barkas et al., 2020; Wu and Khazin, 2020). Specially, Barkas et al. (2020) have built on information on 59 WTO Members across all continents, and provided a systematic approach to map and analyse tourismrelated policies. Wu and Khazin (2020) have provided an overview of the patent landscape of medical treatments and technologies related to COVID-19, as well as the patent status of remdesivir and lopinavir/ritonavir, which are two investigational medical treatments.

Bacchetta et al. (2021) have provided an in-depth analysis of changes in global value chains due to the COVID-19 pandemic. The analysis has been undertaken both from a positive perspective, i.e., by examining expected changes in firms' behaviour, and from a normative angle,

5 Further information on the work undertaken by the UNCTAD could be found online at: https://unctad.org/

${ }^{6}$ Information on the launch of this indicator can be found online at: https://unctad.org/fr/node/32056

7 The category of LDCs has been designated as such by the United Nations as the poorest countries and most vulnerable ones to external and environmental shocks (for further information on LDCs, see online at: https://www.un.org/ohrlls/content/least-developed-countries).

${ }^{8}$ See online at: https://www.wto.org/english/tratop e/covid19 e/covid reports e.htm 
that involves the assessment of the different arguments for policy interventions by governments. Their analysis has shown, inter alia, that countries should give preference to the enhancement of global cooperation than to national policies, such as domestic production and export restrictions. Additionally, the tendency of countries to move away from opening-up their economies to international trade and adopting non-discriminatory trade policies is likely to erode significantly the large benefits to countries and the global economy associated with open trade regimes (e.g., scale economies, innovation spillovers, and a global division of labour).

In addition to its research work in the context of the COVID-19 health crisis, the WTO has been organizing a series of online events to discuss trade policies and trade-related measures that could help its Members not only recover from the current COVID-19 crisis, but also build resilience to future shocks. These include for example, the event whose theme was "economic resilience is the new normal"?"; the event on "the role of international cooperation in economic resilience ${ }^{10 "}$, and the "Aid-for-Trade Stocktaking ${ }^{11}$ Event 2021", which had allowed Members to discuss the trade needs of developing countries and LDCs that had arisen from the COVID-19 outbreak, as well as the mobilization of financial resources for a continued, sustained response that would support recovery and resilience.

Interestingly, the theme of the 2021 WTO Public Forum ${ }^{12}$, which is expected to take place on 28-30 September 2021, is "Trade Beyond COVID-19: Building Resilience". The Forum will consider the effects of the pandemic on trade and how the multilateral trading system can contribute to building resilience to COVID-19 health crisis, and future crises. It will cover three subthemes ${ }^{13}$, including "Enhancing Resilience beyond COVID-19", "Strengthening the Multilateral Trading System" and "Collective Action towards Sustainable Trade".

The current paper aims to contribute to the debate that will take place at the 2021 WTO Public forum by shedding light on the export resilience effect of development aid, in particular Aid for Trade (AfT) flows. Thus, the paper questions whether development aid, in particular Aid for Trade (AfT) flows help recipient countries strengthen their export resilience to shocks.

To the best of our knowledge, this issue has received very little attention in the literature, including from a macroeconomic perspective. The works that are close in spirit to this topic are those that have focused on resilience of global value chains, either through empirically analysis or non-evidence-based analysis (e.g., Bacchetta et al. 2021; Baldwin and Tomiura, 2020; Belhadi et al., 2021; Coveri et al., 2020; Li and Zobel, 2020; Meyer et al. 2020; Miroudot, 2020; National Board of Trade Sweden, 2020; Nordhagen et al., 2021; Rose et al., 2018).

In light of the literature on resilience, including economic resilience (e.g., Briguglio et al., 2009; Gnangnon, 2021c; Guillaumont, 2009, 2017; Hundt and Holtermann, 2020; Jolles et al. 2018;

\footnotetext{
${ }^{9}$ Details on this event as well as presentations by panellists could be found online at: https://www.wto.org/english/res e/reser e/economic resilience 040321 e.htm

10 Details on this event as well as presentations by panellists could be found online at: https://www.wto.org/english/res e/reser e/economic resilience 290421 e.htm

11 See $\quad$ details on this ovent online
https://www.wto.org/english/tratop e/devel e/a4t e/gr21 e/gr21 e.htm\#: :text=The $\% 20$ Aid $\% 2$ Dfor $\% 2$ DTra de $\% 20$ Stocktaking,support $\% 20$ recovery $\% 20$ and $\% 20$ foster $\% 20$ resilience.\&text $=\operatorname{In} \% 20$ this $\% 20$ context $\% 2 \mathrm{C} \% 20$ trad e $\% 20$ has, challenges $\% 20$ raised $\% 20 \mathrm{by} \% 20$ the $\% 20$ pandemic .

${ }^{12}$ The WTO Public Forum is "the organization's largest annual outreach event, which provides a platform for participants to discuss the latest developments in world trade and to propose ways of enhancing the multilateral trading system" (see https://www.wto.org/english/forums e/public forum e/public forum e.htm ).

${ }^{13} \mathrm{https} / /$ www.wto.org/english/forums e/public forum21 e/public forum21 e.htm
} 
Martin and Sunley, 2015; Sondermann, 2018), we define the concept of "export resilience" as the resilience of countries' aggregate exports to shocks. Development aid, also referred to as official development aid (ODA), is the government $\mathrm{aid}^{14}$ that promotes and specifically targets the economic development and welfare of developing countries. AfT flows are part of the total ODA envelop, and aim to help recipient countries, notably LDCs among them "to build the supply-side capacity and trade-related infrastructure that they need to assist them to implement and benefit from WTO Agreements and more broadly to expand their trade" (WTO, 2005, paragraph 57). This arose from the realization by WTO Members that developing countries were suffering from structural impediments ${ }^{15}$ (that prevented them from benefiting from WTO Agreements including through trade promotion) and the subsequent launch at the 2005 WTO Hong Kong Ministerial Conference of the AfT Initiative. Though this Initiative, the WTO advocates for securing greater financial flows in favour of the promotion of the trade sector in its developing Members.

The analysis of the issue as to whether development aid, in particular AfT helps recipient countries strengthen their export resilience, builds essentially on two recent papers. The first paper is by Gnangnon (2021c), and has investigated the effect of productive capacities (as defined by the UNCTAD) on economic resilience in developing countries. The second paper is by Gnangnon (2021d), and has explored the effect of development aid on productive capacities. Both papers used the above-mentioned indicator of productive capacities to perform the empirical analyses. Gnangnon (2021c) has utilized a panel dataset of 118 developing countries over the 2000-2018 period to develop a regression-based indicator of economic resilience. The author has shown that not only does the developing productive capacities help to enhance economic resilience, but development aid is instrumental in achieving this positive economic resilience effect of productive capacities. Specially, countries that obtain higher AfT flows enjoy a higher positive effect of productive capacities on economic resilience. At the same time, NonAfT (i.e., the part of ODA not allocated to the trade-related sector) flows hinder the possible positive effect of productive capacities to economic resilience.

Gnangnon (2021d) has used a set of 111 aid recipient countries over the period 2002-2018 to demonstrate that development aid, including AfT and NonAfT contribute to fostering productive capacities in recipient countries. Additionally, not only has the positive effect of AfT flows on productive capacities been higher than that of NonAfT flows, but both types of development contribute to enhancing productive capacities in LDCs. In contrast, in other countries of the full sample (NonLDCs), only AfT flows matter (including positively) for productive capacities.

The theoretical argument underpinning the analysis of the effect of development aid on recipient countries' export resilience is that this effect works through the productive capacities channel. Thus, development aid, notably AfT flows could contribute to enhancing export resilience by helping recipient-countries to develop their productive capacities.

The current paper is, therefore, essentially empirical. First, it relies upon the first paper, i.e., Gnangnon (2021c) to build the indicator of export resilience. We avoid reproducing here the literature review on the concept of 'resilience', including 'economic resilience' upon which the

14 See the OECD document online at: https://www.oecd.org/dac/financing-sustainabledevelopment/development-finance-standards/What-is-ODA.pdf

15 These included for example, the insufficient development of hard and soft infrastructure that increases trade costs and erodes countries' competitiveness in the international trade market. 
paper would build to develop the indicator of export resilience. Readers can find such a literature review in Gnangnon (2021c) as well as in Martin and Sunley (2015). Second, we do not repeat here the theoretical discussion on how development aid (including both AfT and NonAfT flows) can affect productive capacities, as such a discussion is provided by Gnangnon (2021c).

Against this background, the current analysis goes directly to the issue at hand by taking as an acquis the fact that development aid exert a positive effect on productive capacities in recipient countries. Nonetheless, in the empirical part of the paper, it re-estimates the model specification presented in Gnangnon (2021d) concerning the effect of development aid on productive capacities in order to confirm the empirical findings by Gnangnon (2021d).

The empirical exercise is conducted using an unbalanced panel dataset that contains 93 aid recipient countries over the period 2002-2018. It, first, confirms the findings by Gnangnon (2021d) that development aid influences positively productive capacities in recipient-countries, with AfT flows exerting a higher positive productive capacities effect than NonAfT flows on productive capacities. Second and more importantly, the findings indicate that development aid (including both AfT flows and NonAfT flows) as well as all components of total AfT flows influence positively export resilience in recipient countries.

The rest of the paper is organized around six sections. Section 2 briefly discusses theoretically how development aid can affect export resilience through the enhancement of productive capacities. Section 3 presents the measurement of the export resilience indicator, and Section 4 lays out the model specification that helps to examine the effect of development aid on export resilience. Section 5 discusses the econometric approach to perform the empirical analysis. Section 6 interprets the empirical outcomes, and Section 7 concludes.

\section{Theoretical motivation}

This section discusses theoretically how development aid can affect export resilience through the productive capacities channel. Our definition of export resilience is derived from the definition of economic resilience in the literature, and notably from Guillaumont (2009) (see Gnangnon, 2021c). In fact, the concept of 'economic resilience' is closely related to that of economic vulnerability at the aggregate macroeconomic level (e.g., Briguglio et al. 2009) and in particular to that of structural economic vulnerability (e.g., Guillaumont, 2009). According to Briguglio et al. (2009), the concept of "economic vulnerability" refers to "the inherent permanent (or quasi-permanent) economic features that further expose a country to external shocks, and over which it has almost no control". At the same time, the authors have defined the concept of "economic resilience" as "the policy-induced ability of an economy to recover from or adjust to the negative impacts of adverse exogenous shocks, and to benefit from positive shocks". The definition of "economic vulnerability" by Guillaumont (2009) is more nuanced. The author has defined economic vulnerability as "the risk of a (poor) country seeing its development hampered by the environmental or natural shocks as well as external shocks". He has considered "economic vulnerability" as a combination of a structural component referred to as "structural economic vulnerability", and a conjunctural component referred to as "economic resilience".

The concept of "structural economic vulnerability" encapsulates the level of country's exposure to exogenous shocks, and the size and frequency of these shocks, while "economic resilience" indicates the capacity of the concerned country to react to shocks, such capacity being dependent on recent policy choices that are easily reversible. It is important to note here that the 
definition of structural economic vulnerability by Guillaumont (2009) follows that of the United Nations. The latter have, indeed, used the concept of "structural economic vulnerability" as one of the criteria to identify countries to be included in the category of LDCs. The dataset on the index of structural economic vulnerability has been developed on a retrospective basis by the 'Fondation pour les Etudes et Recherches sur le Développement International (FERDI)' (e.g., Feindouno and Goujon, 2016).

Against this backdrop, we define the concept of "export resilience" as the capacity of countries' aggregate exports to resist to shocks. Resilience of aggregate exports, therefore, depends on measures and policies implemented by countries to make their exports resist to adverse shocks.

We postulate that the effect of development aid on export resilience works through the channel of productive capacities. Thus, if development aid were to influence export resilience through the productive capacities channel, then we would need to discuss theoretically how productive capacities can affect export resilience, insofar as Gnangnon (2021d) has already been provided the theoretical discussion and empirical work on the effect of development aid on productive capacities in recipient countries.

It is noteworthy that productive capacities are defined here as "the productive resources, entrepreneurial capabilities and production linkages which together determine the capacity of a country to produce goods and services and enable it to grow and develop" (UNCTAD, 2006, p61; 2020). The index of overall productive capacities developed by the UNCTAD (see UNCTAD, 2020) on the basis of this definition comprises eight components, which are: physical capital (energy infrastructure; transport infrastructure; information and communication technology, i.e., ICT); human capital; private sector; institutional and governance quality; structural change in production, and natural resources. Hence, the discussion of the effect of productive capacities on export resilience revolves around considering theoretically how each of these factors can affect export resilience.

The literature has now well established that investment in hard infrastructure (e.g., telephone lines, and other ICT, ports, and roads) and soft infrastructure (e.g., border and transport efficiency, and the business and regulatory environment) helps to reduce trade costs (e.g., Deardorff, 2014; Iwanow and Kirkpatrick, 2009; Shepherd, 2010; Olarreaga, 2016) and can therefore help to boost export flows (e.g., Dennis and Shepherd, 2011; Hendy and Zaki, 2021; Khan and Kalirajan, 2011; Portugal-Perez and Wilson, 2012). At the same time, higher trade costs are associated with an expansion of the size of nontradables sector, which, in turn, results in greater volatility of the real exchange rate (e.g., Bravo-Ortega and Di Giovanni, 2006). As the real exchange rate volatility can enhance trade volatility (including export volatility), we infer that trade costs can ultimately lead to lower resilience of exports to shocks. In other words, reducing trade costs through the build-up of hard and soft infrastructure can contribute to fostering export resilience.

Some studies have also underlined that hard quality infrastructure (energy, including electricity, transport) is essential for bolstering countries' resilience to economic and financial shocks, and natural disasters (e.g., Di Caro and Fratesi, 2018; Hallegatte, 2014; Lagravinese, 2015; Taghizadeh-Hesar et al., 2021; United Nations, 2016). In light of the potential adverse effects of natural disasters on international trade flows, including exports (e.g., Andrade da Silva and Cernat, 2012; Gassebner et al., 2010; Oh and Reuveny, 2010; Xu and Kouwoaye, 2019), we expect the development of hard infrastructure to be associated with greater export resilience. 
Incidentally, the promotion of ICT can be associated with a better innovation performance (e.g., Bas, 2020; Higón, 2012; Paunov and Rollo, 2016). In turn, innovation can help to strengthen countries' resilience to climate shocks (e.g., Tambo and Wünscher, 2017), economic and financial shocks (e.g., Bristow and Healy, 2018; Cappelli et al., 2021) or even health shocks such as the COVID-19 pandemic (e.g., Farrugia and Plutowski, 2021; Paunov and Planes-Satorra, 2021; Woolliscroft, 2020). We can, therefore, expect the promotion of ICT to help enhance export resilience through its positive effect on innovation. Overall, development of hard and soft infrastructure can contribute significantly to the enhancement of export resilience.

Human capital accumulation is also critical for export development, as high skilled workers are likely to innovate, produce differentiated goods and hence improve the country's competitiveness in the international market (e.g., Andersson and Johansson, 2010; Contractor and Mudambi, 2008; Munch and Skaksen, 2008). According to Briguglio et al. (2009), the development of human capital can ensure better educational advancement and better health, and in this regard, be instrumental in improving a country's ability to withstand external shocks. This is particularly the case when human capital development helps to sustain a region's technological resilience to adverse shocks (i.e., its level of knowledge creation) in the face of adverse shocks (e.g., Cappelli et al., 2021). This is also the case when it helps to dampen a country's vulnerability to climate change (e.g., Bowen et al., 2012) or when human capital accumulation enhances a country's capacity to develop and implement an effective risk reduction strategy (e.g., Mayunga, 2007). In light of the foregoing, we postulate that human capital accumulation would be associated with greater resilience of export to shocks, as it could help dampen the adverse effects of shocks on exports.

Likewise, natural resource dependence can affect export resilience. Bahar and Santos (2018) have found that countries with larger shares of natural resources in exports tend to have their export baskets more concentrated on non-resource products. Such countries usually experience significant fluctuations of their export product prices (e.g., Asheghian and Saidi, 2002; Athukorola, 2000; Gnangnon, 2021d) and consequently the volatility of export earnings (e.g., Labys and Lord, 1990; Ghosh and Ostry, 1994; Bleaney and Greenaway, 2001; Love, 1983; Massell, 1964). In turn, the volatility of export earnings reduces firms' investments, and make them vulnerable to shocks. This can ultimately lead to a lower resilience of their exports. In addition, a high dependence on natural resources can be a curse for the concerned economy, as such dependence may not only hinder economic development, but it may also crowd out human capital formation (e.g., Wang et al. 2021), which as shown above, could play an essential role in enhancing export resilience. Overall, it is likely that a country with a high share of natural resources in its exports is likely to experience lower levels of export resilience.

The development of the private sector is exemplified, for example, by the development of entrepreneurial activities, the flexibility of product and labour markets, and the development of the domestic financial market. The removal of barriers to entrepreneurship, such as licenses and permit systems and administrative burdens (e.g., Jolles et al., 2018; Seidu and Maciej, 2020) can help to improve the capacity of trading firms to cope with shocks that affect their trade activities (e.g., Andrews and Saia, 2017), and hence the resilience of exports (at the aggregate, i.e., national level) to shocks. Similarly, the flexibility of product markets can influence the speed of the pace of adjustment of firms to shocks by helping to improve the functioning of labour market (e.g., Bassanini and Duval, 2006) and more generally, by promoting the development of business (e.g., Anderton et al., 2020). Additionally, a greater competition in the product markets contributes to 
easing the transmission of monetary and fiscal impulses, including after adverse shocks (e.g., Aghion et al., 2019; Duval and Furceri, 2018). This can strengthen export resilience by facilitating trading firms' access to funding (both provided by the financial sector or the government) and consequently enhancing their ability to address the fallouts of adverse shocks on their activities. The literature has shown that the lack of funding during adverse shocks reduces consumption and particularly investment (e.g., Kinnan and Townsend, 2012; Somville and Vandewalle, 2019), which can reduce countries' level of export resilience. In a nutshell, we expect that a strong private sector in a country would help strengthen its export resilience.

The institutional and governance quality can also be instrumental in promoting greater export resilience. According to the existing literature (e.g., Acemoglu et al., 2003; Caldera Sánchez and Röhn, 2016; Rodrik, 1999), countries with a low quality of institutions and governance have limited ability to withstand external economic shocks. Stronger public administrations improve countries' ability to implement good quality policies, and solve coordination failures across different parts of the administration (e.g., OECD, 2017). Moreover, Zeev and Ifergane (2021) have shown that stringent firing restrictions reduce the capacity of the labour market to respond to adverse shocks. Thus, improving institutional and governance quality would likely help firms, including trading ones deal appropriately with shocks. Against this background, we expect stronger institutions and governance to help foster export resilience.

Finally, structural change in production matters for export resilience. According to Herrendorf et al. (2014, p. 857), structural change in production is defined as a change in the sectoral composition of an economy, i.e., "a reallocation of economic activity across three broad sectors (agriculture, manufacturing, and services) that accompanies the process of modern economic growth". We hypothesize that a greater extent of structural in production is likely to result in greater export resilience. This is because on the one hand, Saltarelli et al. (2020) have demonstrated empirically that goods exports reflect strongly domestic production for manufacturing sectors or sectors related to physical goods, although the link between services export and services production. This means that a greater extent of structural change in production is likely to be strongly associated with greater export diversification, at least for goods exports. On the other, export diversification helps countries dampen output volatility (see above) and reduce firms' output volatility (e.g., Kramarz et al. 2020; Vannoorenberghe et al. 2016), which, in turn, can help firms improve investment and sustain their exports, even after adverse shocks.

Building on the foregone theoretical discussion, we can expect greater productive capacities to be associated with greater export resilience.

Above its effect on export resilience via the productive capacities avenue, development aid can also influence export resilience through its effect on the real exchange rate volatility, although there may be a strong relationship between a country's productive capacities and the level of the volatility of the real exchange rate in this country. In fact, Gnangnon (2020) has obtained empirically that higher AfT flows induce a lower volatility of the real exchange rate, while higher NonAfT flows are associated with an increase in the volatility of the real exchange rate. In light of the possible adverse effects of the real exchange rate volatility on export earnings volatility (i.e., higher real exchange rate volatility would result in fluctuations of export earnings), one can assume that strong fluctuations of the real exchange rate will reduce the resilience of countries' exports to shocks. In this context, we can expect that AfT flows would result in lower levels of export resilience, including through their effects on the volatility of the real exchange. In contrast, 
NonAfT flows can result in lower export resilience due to their positive real exchange volatility effect. Nevertheless, the present paper will not test the real exchange rate volatility channel, and will leave it for future research.

Above all arguments mentioned above, Gnangnon (2021b) has found empirically that productive capacities help reduce economic growth volatility, including by acting as an absorber of shocks. In this way, greater productive capacities can contribute to enhancing export resilience.

Overall, we can expect development aid to help strengthen export resilience, notably in countries with low levels of productive capacities.

\section{Measurement of export resilience}

Building on the definition provided above concerning export resilience and drawing from Gnangnon (2021b), we measure export resilience as the residual of the regression of a variable capturing a country's aggregate exports on the indicator of structural economic vulnerability (denoted "EVI"). The latter measures both countries' exposure to shocks and size of shocks. Thus, the EVI has two main components, i.e., a sub-index of the intensity of exposure to shocks (exposure sub-index) and a sub-index measuring the intensity of exogenous shocks (shocks subindex). These two sub-indexes have been computed as a weighted average of different component indexes, with the sum of components' weights being equal to 1 so that the values of EVI range between 0 and 100 (see Feindouno and Goujon, 2016). The exposure sub-index has five component indexes that are (with their weights in brackets): population size $(25 \%)$, remoteness from world markets $(25 \%)$, exports concentration (12.5\%), share of agriculture, forestry and fishery in GDP $(12.5 \%)$ and share of population living in low elevated coastal zone $(25 \%)$. The shocks sub-index has three components that are (with their weights in brackets): victims of natural disasters (25\%); instability in the agricultural production (25\%); and instability in exports of goods and services $(50 \%)$. An increase in the values of EVI indicates greater structural economic vulnerability.

Hence, by regressing the indicator of a country's aggregate exports on the EVI, we are capturing not only the effect of the extent of shocks faced by the country (i.e., the shock subindex) on exports, but also other structural factors that can affect the development of the country's aggregate exports, such as the population size, the remoteness from world markets, the export concentration, the share of agriculture, forestry and fishery in GDP, and the share of population living in low elevated coastal zone. We discuss below how each of these factors can affect exports.

It can be straightforward to expect that a rise in the size of shocks would lead to fluctuations of exports. This is particularly the case when the adverse shocks result in the tightening of financial conditions by banks and more generally by the financial sector both in the domestic financial market and the international financial markets (e.g., Amiti and Weinstein, 2011; Feng and Lin, 2013; De Nicola and Tan, 2017; Spatareanu et al., 2018). For example, during a global financial crisis (e.g., the 2008 financial crisis), liquidity tightened in the world financial markets, and this raises the costs of trade finance (e.g., Auboin and Meier-Ewert, 2003; Hwang and Im, 2013). Hwang and Im (2013) have found empirically for Korean that financial shocks have generally a negative effect on credit availability, and this negative effect lasts at least three months, which implies significant delays and losses for traders. 
As for the effect of exposure to shocks on exports, we argue that remoteness from the world market increases the costs of participating in international trade, including exporting (e.g., Anderson and van Wincoop, 2001; Coe et al. 2002; Kristjánsdóttir, 2012). The population size is expected to be negatively associated with exports given that countries with a large population populous face relatively lower costs to trade in the domestic market, and benefit from increasing returns (e.g., Esfahani and Ramirez, 2003; Vijil and Wagner, 2012). According to Brun et al. (2005), the population size variable can also be an indicator proxy for relative factor endowments.

Export product concentration can also affect export performance. For example, Camanho and Romeu (2011) have obtained empirically that export product diversification increases export performance. This finding has been confirmed by Funke and Ruhwedel $(2001,2002)$ East Asian countries and Organization for Economic Co-operation and Development (OECD) countries. However, del Rosal (2019) has obtained for Spain that export product concentration influences positively export performance by destination countries. At the same time, a country with a large share of agriculture, forestry and fishery in GDP is likely to export essentially low value-added products, which as we noted above, would result in lower exports. Nevertheless, given that the majority of developing countries rely on export of relatively low value-added products (compared to developed countries), we can argue here that greater export product concentration would be associated with lower export performance, whereas greater export product diversification is likely to be associated with higher export performance.

Finally, countries with a high exposure to natural disasters (measured by the share of population living in low elevated coastal zone) is likely to experience lower export performance because of the higher trade costs induced by the adverse effect of natural disasters on infrastructure (e.g., Kadri et al., 2014; Marto et al., 2018) and human capital (the latter can potentially reduce workers' productivity) (e.g., Paudel and Ryu, 2018).

Overall, in light of the previous discussion, we expect higher structural economic vulnerability to be associated with lower exports (at least aggregate exports).

Having provided a brief theoretical discussion on the effect of structural economic vulnerability on exports, we need now to consider which indicator of export (e.g., real exports versus export volumes) can be used to extract the measure of economic resilience. In the present analysis, we use the real export values (constant US\$, 2010 prices) rather than the volume of exports, given that structural economic vulnerability would likely affect both the volume and prices of exports. The regression has been performed using a panel dataset of 93 aid recipient countries over the period ${ }^{16} 2002-2018$. This is the panel dataset used in the empirical analysis below. The choice of the dataset is dictated by data availability.

Given the limited time dimension of the panel dataset, we do not estimate the export resilience indicator per country, but rather using the panel approach. Therefore, the regression of total real exports (US\$ constant 2010 prices), denoted "EXPORT" over the indicator of structural economic vulnerability (EVI) (both variables are expressed in natural logarithm) is estimated by means of the random effects estimator. In fact, the random effects estimator assimilates only part of the unobserved heterogeneity to structural factors, whereas the fixed effects estimator assimilates the unobserved heterogeneity to structural factors.

16 As used in the empirical analysis, data has been averaged over non-overlapping sub-periods of 3 -year. These sub-periods are: 2002-2004; 2005-2007; 2008-2010; 2011-2013; 2014-2016 and 2017-2018. 
The outcome of this regression is as follows: $\log ($ EXPORT $)=-1.658 * \log (\mathrm{EVI})+28.5$

Within $\mathrm{R}^{2}=0.12$; Between $\mathrm{R}^{2}=0.544$; Overall $\mathrm{R}^{2}=0.523$; Number of countries $=93$; Number of observations $=519$. The coefficients in brackets are robust standard errors.

These results show, as expected, that higher structural economic vulnerability is significantly associated (at the $1 \%$ level) with lower real exports.

The indicator of export resilience denoted "RESIL" is computed as the residual of the regression (1). It represents a measure of 'relative' export resilience across countries in the full sample, given that the mean of the residuals amounts to zero. As reported in Appendix 2, values of the indicator of export resilience over the full sample range between -0.87 and 1.44, with the mean being 0.11 and the standard deviation amounting to 0.25 . A rise in the value of this indicator reflects greater export resilience, while lower values indicate lower level of export resilience.

Figure 1 displays a graphical representation of the development of several key indicators over the panel dataset of 93 countries with data spanning the period 2002-2018. These indicators include the indicator of export resilience, the indicator of overall productive capacities denoted "PCI", the aid variables, namely total development aid denoted "ODA", and its two components, which are total AfT flows denoted "AfT" and NonAfT flows denoted "NonAfT". The last indicator is the share of total AfT flows in total ODA flows, denoted "ShAfT". All aid variables are real gross disbursements of aid, and expressed in constant prices 2018, US Dollar.

Figure 2 shows the correlation pattern in the form of cross-plot between the indicator of overall productive capacities and total development aid flows, on the one hand, and between the index of export resilience and total development aid flows on the other hand.

Figure 3 provides the correlation pattern between the indicator of export resilience and each of the two components of total ODA flows, namely total AfT flows and total NonAfT flows.

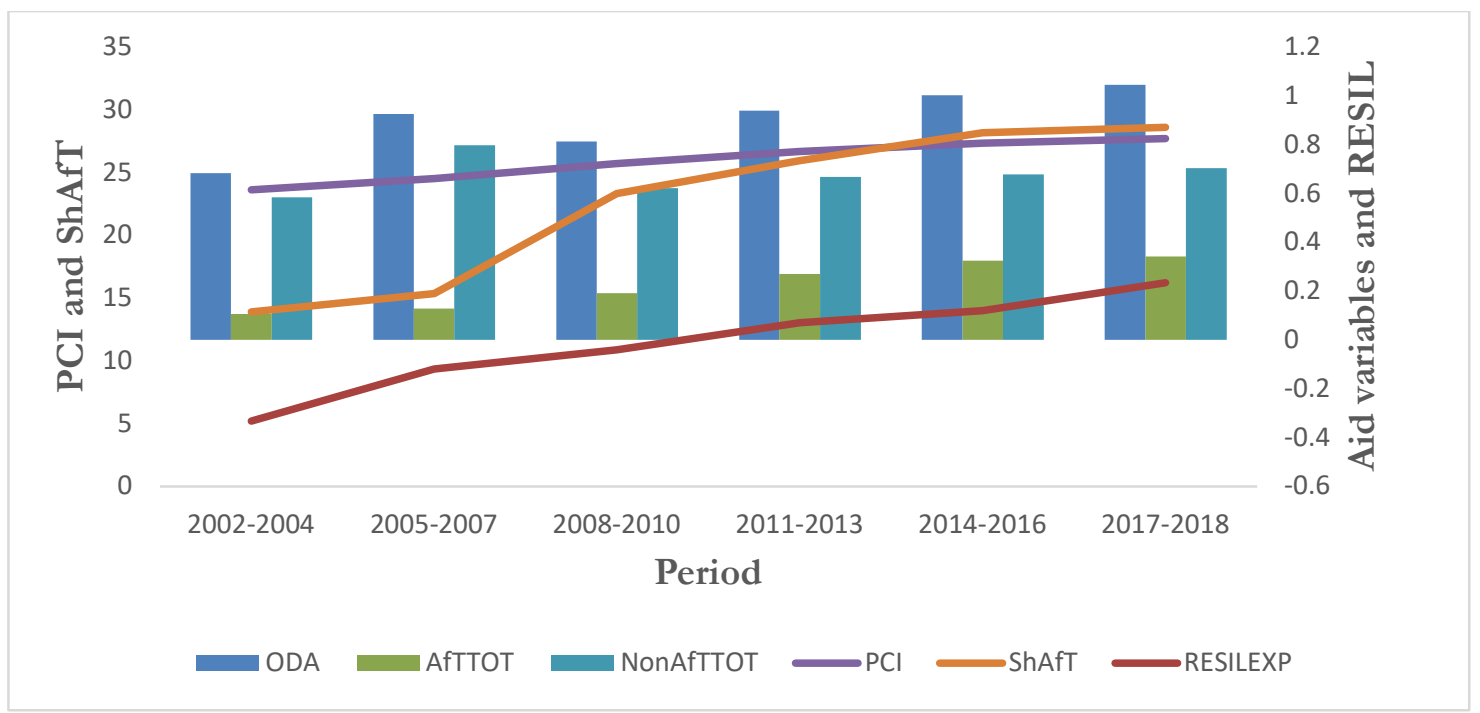

Figure 1: Development aid, productive capacities and export resilience_Over the full sample Source: Author

Note: The variables "ODA", "AfTTOT" and "NonAfTTOT" are respectively the gross disbursement of total OD A flows, AfT flows, and Other Aid flows, and are all expressed in billion US\$, Constant 2018 Prices. The 
variable "ShAfT" is the share (\%) of gross disbursements of total AfT flows in gross disbursements of total ODA, -both aid variables being expressed in US\$, Constant 2018 Prices.

Figure 1 suggests that developing countries improved their level of productive capacities over time, from 23.6 in 2002-2004 to 27.72 in 2017-2018. Likewise, their level of export resilience steadily increased over time, from -0.33 in 2002-2004 to 0.23 in 2017-2018. Total development aid flows fluctuated over the full period. It increased from US\$ billion 0.684 in 2002-2004 to US\$ billion 0.926 in 2005-2007, and then declined to reach US $\$$ billion 0.812 in 2008-2010. From 20082010 onwards, it experienced a steady rise to reach US\$ billion 1.05 in 2017-2018. This development of total development aid flows is reflected in the development of NonAfT flows over the full period and sample. In particular, NonAfT flows experienced an upward movement from US $\$$ billion 0.584 in 2002-2004 to US $\$$ billion 0.798 in 2005-2007, and then fell to US $\$$ billion 0.62 in 2008-2010. NonAfT flows then steadily moved upward to reach billion US\$ 0.703 in 20172018. On the other side, the amounts of AfT that accrued to developing countries remained lower than the amounts of NonAfT. In contrast with the ups-and-downs movements of NonAfT flows, AfT flows constantly increased from US\$ billion 0.106 in 2002-2004 to US\$ billion 0.342 in 20172018. This movement of total AfT flows is reflected in the share (\%) of AfT flows in total ODA. Specially, this share rose from $13.9 \%$ in $2002-2004$ to $28.6 \%$ in $2017-2018$. The set-up of the AfT initiative in 2005 certainly contributes to this rise in the AfT flows over time (see Gnangnon, 2019a).
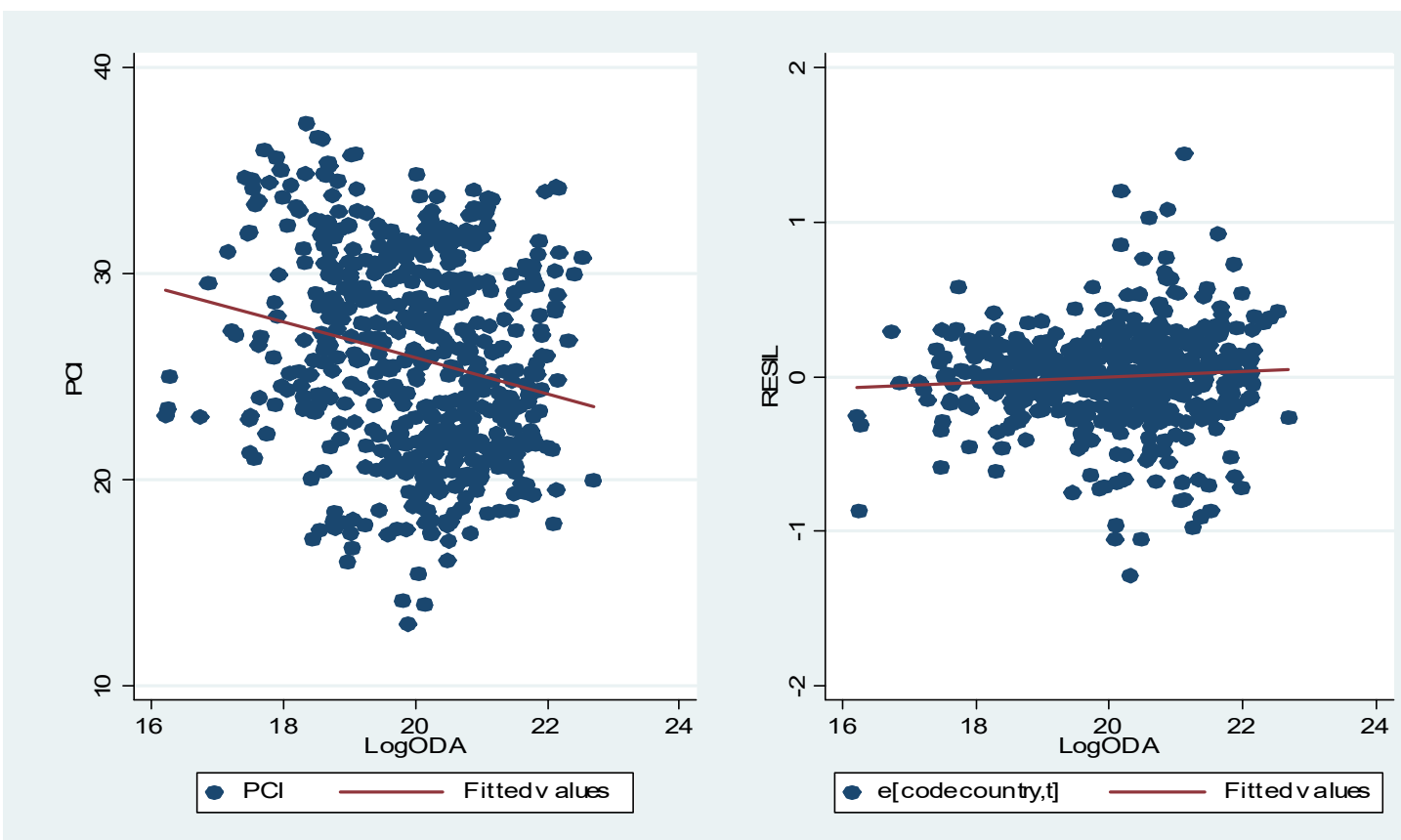

Figure 2: Cross plot between total ODA, productive capacity and export resilience_over the full sample

Source: Author

Figure 2 suggests a negative correlation between total development aid and the overall productive capacities, while there is no-clear correlation pattern between export resilience and total development aid. 

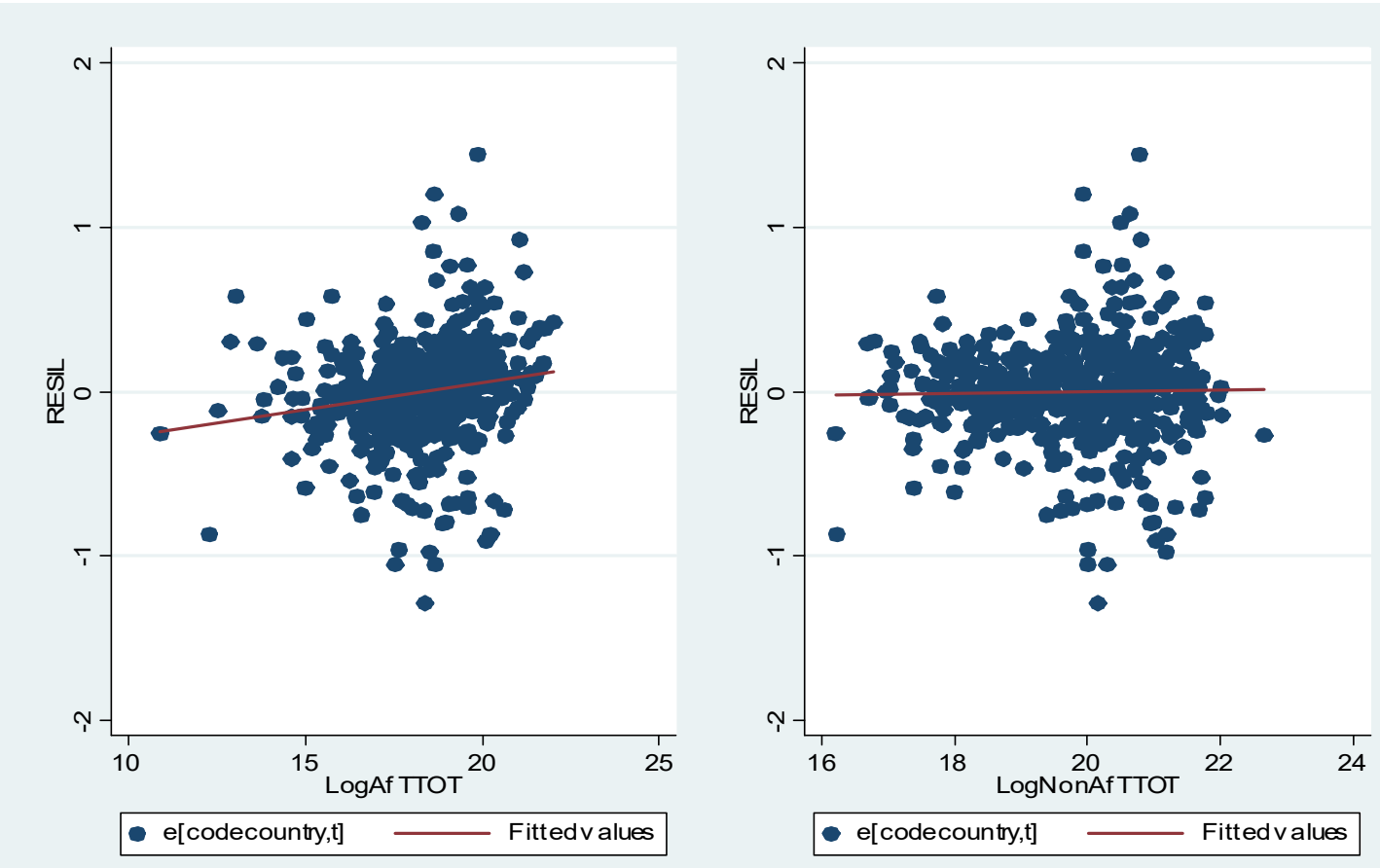

Figure 3: Cross plot between AfT flows, NonAfT flows and export resilience_over the full sample Source: Author

Figure 3 also indicates that the correlation pattern between export resilience and total NonAfT flows is unclear. In contrast, we find a strong positive correlation pattern between export resilience and total AfT flows.

\section{Model specification}

There is no specific theoretical framework on the macroeconomic determinants of export resilience. Nevertheless, as the indicator of export resilience is derived from a regression of the indicator of real export values over the indicator of structural economic vulnerability, we build on the literature on the determinants of export performance to determine our model specification (e.g., Bearce et al., 2013; Calì and te Velde, 2011; Gnangnon, 2019b; Gradeva and Martínez-Zarzoso, 2015; Ju et al., 2010; Santos-Paulino, 2007; Vijil and Wagner, 2012). As we expect theoretically that development aid would influence export resilience through its effect on the overall productive capacities (including the eight components of the latter), we consider a baseline model where aid recipient countries' export resilience depends on the development aid flows as well as other structural factors, such as their level of real per capita income, trade policy, and financial openness. All these variables are described in Appendix 1.

The baseline model considered takes the following form:

RESIL $_{\text {it }}=\beta_{0}+\beta_{1}$ RESIL $_{\mathrm{it}-1}+\beta_{2} \log (\text { AID })_{\mathrm{it}}+\beta_{3} \log (\mathrm{GDPC})_{\mathrm{it}}+\beta_{4} \log (\mathrm{TP})_{\mathrm{it}}+\beta_{5}$ FINPOL $_{\mathrm{it}}+$ $\beta_{6}$ FINPOL $_{i t}^{2}+\mu_{\mathrm{i}}+\gamma_{\mathrm{t}}+\omega_{\mathrm{it}}$ 
where $\mathrm{i}$ and $\mathrm{t}$ are respectively the subscripts for a country and the time-period. As noted above, the panel dataset used contains 93 countries over the period 2002-2018, with data averaged over non-overlapping 3-year sub-periods to smooth out the effect of business cycles on variables at hand. The sub-periods are: 2002-2004; 2005-2007; 2008-2010; 2011-2013; 2014-2016 and 20172018 (this last sub-period covers 2 years). $\beta_{0}$ to $\beta_{6}$ are coefficients that will be estimated. $\mu_{\mathrm{i}}$ are countries' specific effects. $\gamma_{\mathrm{t}}$ represent time dummies, i.e., global shocks that affect simultaneously all countries' export resilience. $\omega_{\text {it }}$ are random error terms.

To recall, the dependent variable "RESIL" is the indicator of export resilience. The one period lag of this variable has been introduced as a regressor in model (1), with a view to addressing the eventual problem of omitted variables in model (1). In addition, this variable helps to account for the possible inertia in export resilience, i.e., a possible state dependence in export resilience.

The variable "AID" is the development aid variable. It could be the total development aid ("ODA") or its two components, i.e., AfT flows ("AfT"), and NonAfT flows ("NonAfT"). In light of close (direct) link between AfT flows and the development of productive capacities, and given the importance of productive capacities (through their trade costs reduction effect) for export performance in aid recipient countries, we additionally examine how each of the three components of total AfT flows - as defined by the Organisation for Economic Co-operation and Development (OECD) - affects export resilience. These three components of total AfT flows are AfT flows for the build-up of economic infrastructure denoted "AfTINFRA", AfT flows for building productive capacities, denoted "AfTPROD", and AfT flows related to trade policy and regulation, denoted "AfTPOL". Like other aid variables, all three AfT components are real gross disbursements, and expressed in constant prices 2018, US dollar.

The variables "GDPC", "TP" and "FINPOL" represent respectively the real per capita income, the trade policy, and the financial openness, i.e., capital account openness. The descriptive statistics on all variables in model (2) are provided in Appendix 2.

All regressors except for the variable measuring the level of capital account openness (denoted "FINPOL") are transformed using the natural logarithm. This is because the variable "RESIL" is extracted as a residual of a regression (1) where the dependent variable and the regressor have been transformed using the natural logarithm. The variable "FINPOL" cannot be transformed into natural logarithm because its values range between 0 and 1 , and it additionally, does not have a skewed distribution.

The coefficients of all regressors (excluding "FINPOL") in model (2) will be interpreted in terms of elasticity. It is also important to stress that the introduction of the squared term of the financial openness variable in model (2) is not guided by a theoretical framework ${ }^{17}$, but rather by an intuition, in particular, the realization when running regressions that there is a non-linear effect of financial openness on export resilience. This relationship between financial openness and export resilience would need to be deeply investigated in future research. For the time being, we consider this variable as a control variable in model (2).

As for the effect of control variables on export resilience, we expect that aid recipient countries that have a high real per capita income are likely to experience a higher level of export resilience than those with a lower real per capita income. This is because such countries are not only likely to have greater trade capacity than less advanced countries, but they are also likely to have much more resources (e.g., financial and human capital resources) than countries with lower income levels (e.g., poorest

\footnotetext{
${ }^{17}$ As mentioned earlier, there is no theoretical framework on the determinants of export resilience.
} 
countries) to cope with shocks that would affect their exports. Thus, we expect the rise in the real per capita income to be associated with greater export resilience.

Trade policy can affect export resilience. In the wake of the COVID-19 pandemic, there have been calls for countries to refrain from adopting restrictive trade policies. This is because restrictive trade policies would further depress economies (by adding to the effect of the health crisis) by severely restricting trade flows, notably exports of products needed to fight the pandemic (e.g., Bacchetta et al. 2021; Baldwin and Evenett, 2020). Restrictive trade measures would also shrink the insurance role of GVCs as well as their capacity to foster the resilience of economies during the pandemic (e.g., National Board of Trade Sweden, 2020).

Trade policy liberalization can expose countries to shocks (e.g., Montalbano, 2011), enhance countries' vulnerability to shocks, and may consequently reduce their level of export resilience. In such a case, greater trade policy liberalization would be associated with lower export resilience. At the same time, trade policy liberalization can also help countries improve their innovation performance by allowing for knowledge diffusion, and transfer of technology (e.g., Aghion et al., 2005; Coelli et al., 2016; Grossman and Helpman, 2015), or enhancing export product diversification (e.g., Aditya and Acharyya, 2015; Osakwe et al., 2018) or improve the complexity of economies (e.g., Sepehrdoust et al., 2019). In turn, greater export diversification can lead to lower output volatility and hence increase countries' capacity to withstand external shocks (e.g., Balavac et al., 2016; Haddad et al., 2013). Similarly, greater economic complexity is associated with lower economic growth volatility (e.g., Güneri and Yalta, 2020; Maggioni et al., 2016; Miranda-Pinto, 2021) as well as lower economic growth cycles (e.g., Canh and Thanh, 2020). Given that export resilience could be greater in the context of lower output volatility, we infer that trade policy liberalization would ultimately be associated with greater export resilience through its positive effect on innovation, export product diversification (or economic complexity). Overall, the net effect of trade policy liberalization on export resilience is a priori unknown and would be determined empirically. This effect will, in particular be negative if such liberalization does not lead countries to diversify their exports towards higher value added products (and services) and lock them into the export of products with low value added (which is the case of LDCs where export diversification is very limited).

On another note, greater financial openness allows firms to have access to a wide range of financial instruments, including at lower costs, and hence enhances their capacity to better diversify risks, and improve the efficiency in resources allocation (e.g., Acemoglu and Zilibotti, 1997; Ariss, 2016; Obstfeld, 1994; Schmukler and Vesperoni, 2006; Stulz, 1999). In this context, greater financial openness can be associated with greater export resilience. Similarly, higher inflows of foreign direct investment (FDI) (due to greater financial openness) can result in lower real exchange rate volatility (e.g., Al-Abri, 2013; Al-Abri and Baghestani, 2015). This is because higher FDI inflows can improve factor productivity, and stabilize both domestic consumption and investment spending through international risk-sharing (e.g., Agenor, 2003) and greater competition and integration in both products and factors markets (e.g., Markusen and Venables, 1999). As the volatility of the real exchange rate could induce greater volatility of exports, we expect that higher FDI inflows (due to greater financial openness) could ultimately result in improved levels of export resilience. On the other side, if greater financial openness amplifies financial distortions (e.g., Eichengreen and Leblang, 2003), then it will not help enhance countries' export resilience. Overall, the net effect of financial openness on export resilience is a priori undetermined theoretically. Only the empirical exercise would provide a clear answer to this issue. 


\section{Econometric approach}

As we hypothesized that the effect of development aid on export resilience would work through the productive capacities channel, we find useful to start the empirical analysis by replicating here the empirical work by Gnangnon (2021d). To recall, the latter has investigated the effect of development aid on the overall productive capacities. We use the model specification defined by the author, whereby the indicator of the overall productive capacities is regressed over its lags (one-period lag and twoperiod lag), the development aid variable and a set of control variables. The latter include trade openness ("OPEN"), the share of total revenue (excluding grants and social contributions) in GDP (denoted "TOTREV"), the real per capita income "GDPC", and the indicator of financial openness. Note that for the sake of the analysis, the variables "OPEN" and "TOTREV" are not expressed in percentage. Aid variables include total development aid, its components (AfT flows and NonAfT flows) as well as the components of total AfT flows, each aid variable being included once at a time in the regression. We refer the readers to Gnangnon (2021d) for the theoretical effects of these regressors. The description of all these variables as well as their respective source are provided in Appendix 1, while descriptive statistics concerning them are displayed in Appendix 2.

Like in Gnangnon (2021d), all model specifications concerning the effect of development aid on the overall productive capacities, including with each aid variable, are estimated by means of the two-step system Generalized Methods of Moments (GMM) estimator of Blundell and Bond (1998). This involves estimating a system of equations that contains an equation in first differences and an equation in the levels. Lagged first differences of variables are used as instruments for the level equation, and lagged levels of variables are used as instruments for the first-difference equation. Similarly, following Gnangnon (2021d), aid variables and the variables "OPEN", "TOTREV", "FINPOL" and "GDPC" have been treated as endogenous. The estimates arising from these regressions are reported in Table 1. Three lags of the dependent variables and two lags of endogenous variables have been used as instruments in the regressions in order to meet the requirements of the two-step system GMM technique, while also avoiding over-instrumentation. These requirements include the presence of a first-order serial correlation in the residuals of the equations in level, tested by means of the Arellano-Bond test (i.e., AR(1) test); the absence of a second-order autocorrelation in the residual of the differenced equation, tested by means of the Arellano-Bond test (i.e., AR(2) test); and the Sargan/Hansen test of over-identifying restrictions, which tests the null hypothesis of the joint validity of the instruments used in the system of equations.

Model (2), including specifications of this model with each aid variable, are also primarily estimated using the two-step system GMM estimator. Aid variables and the variables "TP", "FINPOL", the squared term of the latter and the variable "GDPC have been treated as endogenous because of the possible bi-directional causality between the dependent variable and each of these regressors. This can be justified by the fact that even though we expect development aid flows to influence export resilience in recipient countries, we cannot rule out the possibility that countries with low export resilience (for example those where firms have little access to funding because of shallow domestic financial markets or because access to international markets is very hard) might receive high amounts of development aid, including AfT flows from donorcountries. Low levels of export resilience may also motivate countries to further liberalize their trade policies if they believe that the possible transfer of technology and innovation arising from greater trade policy liberalization can be instrumental in developing high quality export products 
and hence strengthening their export resilience. The same reasoning applies to the financial openness variable. For example, countries vulnerable to shocks, that have concurrently low levels of export resilience and low degree of financial openness may opt for further opening-up their capital account, insofar as the latter could help firms have access to funding at low costs during crises. Finally, strengthening export resilience can contribute to improving the trading firms' income, promote exports, which can, in turn, improve countries' levels of the real per capita income (in light of the possible positive relationship between export performance and the real per capita income).

The estimation of model (2) as well as several of its variants presented below also uses 3 lags of the dependent variables and 2 lags of endogenous variables as instruments. Even though the two-step system GMM is our main technique to estimate model (2) and its different variants, it is might be useful starting the analysis of the effect of development aid on export resilience by estimating several specifications of model (2) (i.e., with each of the aid variables described above) without the lagged dependent variable as regressor. In these specifications, all regressors have been considered with a one-period lag, with a view to mitigating the endogeneity concerns relating to these variables. These specifications of model (2) are estimated using the within fixed effects estimator where standard errors have been corrected using the approach of Driscoll and Kraay (1998). This approach helps to take into account the heteroscedasticity, autocorrelation and crosssectional dependence in the dataset. The results of the estimation of these different specifications of the static version of model (2) (i.e., with different aid variables) are presented in Table 2.

Next, we move to the different variants of the dynamic model (2) estimated using the twostep system GMM approach. It is important to underline here that when estimating all specifications of the dynamic model (2), we noticed that using only the one-period lag of the dependent variable as a regressor was not sufficient to meet the conditions set out above for the validity of the two-step system GMM technique. Rather, the use of both the one-period and the two-period lag of the dependent variable as regressors in the dynamic model (2) helped to meet these conditions for the validity of the two-step system GMM estimator. This surely due to the strong state-dependence nature of the export resilience indicator.

Table 3 contains the outcomes obtained by estimating the dynamic model (2) where the variable "AID" is measured by each of the aid variables (i.e., total development aid, AfT flows, NonAfT flows, and each of the three components of AfT flows). These outcomes serve to examine the effect of development aid on export resilience.

Columns [3] to [8] of Table 4 contains the estimates arising from the estimation of many other variants of the dynamic model (2) in which we introduce the indicator of overall productive capacities, and where each aid variable has been interacted with the indicator of the overall productive capacities. These outcomes serve to examine whether the effect of development aid on export resilience works through the productive capacities channel. In column [1] of this Table, we present the results arising from the estimation of a specification of model (2) where the variable "AID" has been replaced with the indicator of the overall productive capacities. The objective of doing so is to examine the effect of the overall productive capacities on export resilience in the absence of the aid variable in the model. Column [2] of the same Table reports the outcomes of the estimation of another variant of model (2) in which we include both the total development aid variable and the indicator of productive capacities (expressed in natural logarithm). If both variables hold significant coefficients (notably if these coefficients are positive), we can deduce 
that there are likely other channels (in addition to the productive capacities) through which development aid can affect export resilience. In contrast, if one variable (for example the index "PCI") has a statistically significant coefficient, while the other variable does not have a significant coefficient), then we can infer that the effect of development aid on export resilience translates essentially through the productive capacities channel.

Tables 5 and 6 report outcomes that allow checking the robustness of results reported respectively in Tables 3 and 4. In fact, we observed the presence of some outliers in the right-hand side graph of Figure 2, and in the two graphs of Figure 3. These outliers concern notably countries where values of the indicator of export resilience are higher than 1 and lower than -1 . Four outliercountries (Burkina Faso; Guinea; Malawi; Sierra Leone) meet these conditions. We, therefore, exclude these four countries from the sample, and re-run two sets of regressions: the first one concerns the different specifications of model (2) whose results are reported in Table 3, and the second set of regressions concerns the different specifications of model (2) whose results are reported in Table 4. The outcomes of the first set of regressions are presented in Table 5, while the results of the second set of regressions are displayed in Table 6.

\section{Interpretation of empirical outcomes}

At the outset, we would like to note that the results of the diagnostic tests used to test the validity of the two-step system GMM estimator (see the bottom of Table 1 and Tables 3 to 6) confirm that this estimator can be appropriate to perform the empirical analysis. As obtained by Gnangnon (2021d), the two lags of the dependent variable in Table 1 have statistically significant coefficients (at the 1\% level). These results suggest that the indicator of overall productive capacities displays a strong state dependence path. Likewise, the indicator of export resilience also shows a strong state dependence path, whereby export resilience in period $\mathrm{t}-1$ and export resilience in period $\mathrm{t}-2$ influence respectively positively and negatively (at the 1\% level) export resilience in period t. In Table 1 and Tables 3 to 6 , the p-values of the $\operatorname{AR}(1)$ and $\operatorname{AR}(2)$ tests are respectively lower than 0.10 (i.e., the $10 \%$ level of statistical significance) and higher than 0.10 . Additionally, the $\mathrm{p}$-values of the over-identifying restrictions test are always higher than $10 \%$, thereby indicating the joint validity of instruments used in the regressions.

Table 1: Effect of development aid on productive capacities Estimator. Two-Step System GMM

\begin{tabular}{|c|c|c|c|c|c|c|}
\hline & PCI & PCI & PCI & PCI & PCI & PCI \\
\hline & $(1)$ & $(2)$ & $(3)$ & $(4)$ & $(5)$ & $(6)$ \\
\hline & $1.112^{* * *}$ & $1.036^{* * *}$ & $1.121^{* * *}$ & $1.065^{* * *}$ & $1.040^{* * *}$ & $1.048^{* * *}$ \\
\hline PCI $_{\mathrm{t}-1}$ & $(0.0423)$ & $(0.0449)$ & $(0.0426)$ & $(0.0474)$ & $(0.0495)$ & $(0.0425)$ \\
\hline & $-0.188^{* * *}$ & $-0.188^{* * *}$ & $-0.187^{* * *}$ & $-0.213^{* * *}$ & $-0.173^{* * *}$ & $-0.156^{* * *}$ \\
\hline PCI $_{\mathrm{t}-2}$ & $(0.0345)$ & $(0.0377)$ & $(0.0348)$ & $(0.0407)$ & $(0.0426)$ & $(0.0397)$ \\
\hline $\log (\mathrm{ODA})$ & $0.241^{* * *}$ & & & & & \\
\hline $\log ($ AfTTOT) & $(0.0556)$ & & & & & \\
\hline & & $0.239^{* * *}$ & & & & \\
\hline & & $(0.0271)$ & & & & \\
\hline
\end{tabular}




\begin{tabular}{|c|c|c|c|c|c|c|}
\hline \multirow[t]{2}{*}{$\log ($ NonAfTTOT) } & & & $0.216^{* * *}$ & & & \\
\hline & & & $(0.0631)$ & & & \\
\hline \multirow[t]{2}{*}{ Log(AfTINFRA) } & & & & $0.161 * * *$ & & \\
\hline & & & & $(0.0276)$ & & \\
\hline \multirow[t]{2}{*}{$\log ($ AfTPROD $)$} & & & & & $0.252^{* * *}$ & \\
\hline & & & & & $(0.0439)$ & \\
\hline \multirow[t]{2}{*}{ Log(AfTPOL) } & & & & & & $0.0956^{* * *}$ \\
\hline & & & & & & $(0.0234)$ \\
\hline \multirow[t]{2}{*}{ OPEN } & 0.104 & 0.256 & 0.0712 & 0.204 & 0.101 & 0.240 \\
\hline & $(0.212)$ & $(0.172)$ & $(0.204)$ & $(0.200)$ & $(0.198)$ & $(0.189)$ \\
\hline \multirow[t]{2}{*}{ TOTREV } & 0.360 & 0.0516 & 0.732 & 0.0496 & $1.008^{*}$ & 0.0336 \\
\hline & $(0.539)$ & $(0.527)$ & $(0.563)$ & $(0.515)$ & $(0.588)$ & $(0.716)$ \\
\hline \multirow[t]{2}{*}{ FINPOL } & $0.972^{* * *}$ & $0.996^{* * *}$ & $0.940 * * *$ & $0.866^{* * *}$ & $1.383 * * *$ & $1.047 * * *$ \\
\hline & $(0.158)$ & $(0.153)$ & $(0.170)$ & $(0.159)$ & $(0.151)$ & $(0.150)$ \\
\hline \multirow[t]{2}{*}{$\log ($ GDPC $)$} & $0.402^{* * *}$ & $0.626^{* * *}$ & $0.367 * * *$ & $0.610^{* * *}$ & $0.538^{* * *}$ & $0.431 * * *$ \\
\hline & $(0.0945)$ & $(0.110)$ & $(0.0933)$ & $(0.106)$ & $(0.0776)$ & $(0.0832)$ \\
\hline \multirow[t]{2}{*}{ Constant } & $-5.909 * * *$ & $-5.354 * * *$ & $-5.374 * * *$ & $-3.704 * * *$ & $-5.357 * * *$ & $-1.906^{* * *}$ \\
\hline & $(1.413)$ & $(0.781)$ & $(1.579)$ & $(0.752)$ & $(0.967)$ & $(0.472)$ \\
\hline Observations - Countries & $321-87$ & $321-87$ & $321-87$ & $321-87$ & $321-87$ & $319-87$ \\
\hline Number of Instruments & 51 & 51 & 51 & 51 & 51 & 51 \\
\hline AR1 (P-Value) & 0.0009 & 0.0010 & 0.0012 & 0.0011 & 0.0021 & 0.0054 \\
\hline AR2 (P-Value) & 0.9613 & 0.9189 & 0.9826 & 0.9652 & 0.9530 & 0.8480 \\
\hline OID (P-Value) & 0.3518 & 0.6664 & 0.3316 & 0.5059 & 0.7017 & 0.6199 \\
\hline
\end{tabular}

Note: ${ }^{*}$-value $<0.1$; ** $p$-value $<0.05$; ***-value $<0.01$. Robust standard errors are in parenthesis. The aid variables and the variables "OPEN", "TOTREV", "FINPOL" and "GDPC" have been treated as endogenous. Time dummies have been included in the regressions. The latter have used a maximum of 3 lags of the dependent variable as instruments, and 2 lags of endogenous variables as instruments.

The results in Table 1 confirm the findings by Gnangnon (2021d) that higher development aid flows exert a positive effect on productive capacities. In fact, we obtain here (as in Gnangnon, 2021d) that the coefficients of all aid variables are positive and significant at the $1 \%$ level, thereby suggesting that all aid variables, including total development aid, its two components (namely total AfT flows and NonAfT flows), as well as the three components of total AfT flows influence positively and significantly productive capacities. It appears that total AfT flows exert a slightly higher positive effect (in terms of the magnitude of the effect) on the overall productive capacities than NonAfT flows. Additionally, among AfT components, AfT interventions for productive capacities building exert the highest positive effect (in terms of magnitude, which is 0.252 ) on productive capacities. This is followed by AfT interventions for economic infrastructure (the magnitude of the effect being 0.161) and AfT interventions for trade policy and regulation (the magnitude of the effect being 0.096). As regard control variables, we observe that the rise in the real per capita income and greater financial openness are positively associated with the development of productive capacities. At the conventional significance levels, trade openness and public revenue do not affect the overall productive capacities. 
Table 2: Effect of development aid on export resilience Estimator: Within Fixed Effects

\begin{tabular}{|c|c|c|c|c|c|c|}
\hline Variables & RESIL & RESIL & RESIL & RESIL & RESIL & RESIL \\
\hline & $(1)$ & $(2)$ & (3) & $(4)$ & $(5)$ & $(6)$ \\
\hline \multirow[t]{2}{*}{$\log (\mathrm{ODA})_{\mathrm{t}-1}$} & $0.0974 * * *$ & & & & & \\
\hline & $(0.0351)$ & & & & & \\
\hline \multirow[t]{2}{*}{$\log (\text { AfTTOT })_{t-1}$} & & $0.0433^{* * *}$ & & & & \\
\hline & & $(0.00253)$ & & & & \\
\hline \multirow[t]{2}{*}{$\log (\operatorname{NonAfTTOT})_{t-1}$} & & & $0.0814^{* *}$ & & & \\
\hline & & & $(0.0377)$ & & & \\
\hline \multirow[t]{2}{*}{$\log (\text { AfTINFRA })_{t-1}$} & & & & $0.0201 * * *$ & & \\
\hline & & & & $(0.00629)$ & & \\
\hline \multirow[t]{2}{*}{$\log (\text { AfTPROD })_{\mathrm{t}-1}$} & & & & & $0.0264 * *$ & \\
\hline & & & & & $(0.0106)$ & \\
\hline \multirow[t]{2}{*}{$\log \left(\right.$ AfTPOL) ${ }_{\mathrm{t}-1}$} & & & & & & $0.0235^{* * *}$ \\
\hline & & & & & & $(0.00324)$ \\
\hline \multirow[t]{2}{*}{$\log (\text { GDPC })_{t-1}$} & $0.777 * * *$ & $0.714^{* * *}$ & $0.817 * * *$ & $0.745^{* * *}$ & $0.760 * * *$ & $0.786^{* * *}$ \\
\hline & $(0.0255)$ & $(0.0280)$ & $(0.0301)$ & $(0.0306)$ & $(0.0269)$ & $(0.0391)$ \\
\hline \multirow[t]{2}{*}{$\log (\mathrm{TP})_{\mathrm{t}-1}$} & $0.182^{* * *}$ & $0.195^{* * *}$ & $0.210 * * *$ & $0.207 * * *$ & $0.230 * * *$ & $0.179 * * *$ \\
\hline & $(0.0514)$ & $(0.0569)$ & $(0.0475)$ & $(0.0674)$ & $(0.0534)$ & $(0.0588)$ \\
\hline \multirow[t]{2}{*}{ FINPOL $_{\mathrm{t}-1}$} & $-0.368 * * *$ & $-0.396 * * *$ & $-0.306 * * *$ & $-0.320 * * *$ & $-0.330 * * *$ & $-0.360 * * *$ \\
\hline & $(0.107)$ & $(0.0900)$ & $(0.102)$ & $(0.0958)$ & $(0.0923)$ & $(0.115)$ \\
\hline \multirow[t]{2}{*}[\text{FINPOL}_{\mathrm{t}-1}]{$^{2}$} & $0.381 * * *$ & $0.423^{* * *}$ & $0.326^{* * *}$ & $0.371 * * *$ & $0.367 * * *$ & $0.347 * *$ \\
\hline & $(0.109)$ & $(0.111)$ & $(0.114)$ & $(0.128)$ & $(0.0991)$ & $(0.137)$ \\
\hline \multirow[t]{2}{*}{ Constant } & $-8.595 * * *$ & $-7.004 * * *$ & $-8.683^{* * *}$ & $-6.869 * * *$ & $-7.187 * * *$ & $-7.012^{* * *}$ \\
\hline & $(0.742)$ & $(0.326)$ & $(0.932)$ & $(0.357)$ & $(0.359)$ & $(0.359)$ \\
\hline Observations - Countries & $427-93$ & $426-93$ & $426-93$ & $426-93$ & $426-93$ & $420-93$ \\
\hline Within $\mathrm{R}^{2}$ & 0.2588 & 0.2493 & 0.2538 & 0.2455 & 0.2438 & 0.2670 \\
\hline
\end{tabular}

Note: *p-value $<0.1 ;{ }^{* *} p$-value $<0.05 ; * * *$-value $<0.01$. Robust standard errors are in parenthesis.

Taking-up results in Table 2 (results based on the fixed effects approach), we obtain that at the $5 \%$ level, all development aid variables influence positively and significantly export resilience. Specially, total development aid flows drive positively export resilience, and this finding reflects a higher positive effect of NonAfT flows than that of AfT flows on export resilience. Within the category of AfT flows, we obtain that all three components of total AfT flows influence positively export resilience with almost the same magnitude of the effect. Thus, we can examine later in the analysis whether the effect of development aid on productive capacities works through the avenue of the overall productive capacities. Regarding control variables, it appears that an improvement in the real per capita income and greater trade policy liberalization are associated with greater export resilience. Finally, at the 1\% level, there is a non-linear effect of financial openness on export resilience in the form of an inverted-U curve: low degree of financial openness is associated with low levels of export resilience, and export resilience becomes stronger for high degrees of financial openness. 
Table 3: Effect of development aid on export resilience

Estimator: Two-Step System GMM

\begin{tabular}{|c|c|c|c|c|c|c|}
\hline Variables & RESIL & RESIL & RESIL & RESIL & RESIL & RESIL \\
\hline & (1) & (2) & (3) & (4) & (5) & (6) \\
\hline RESIL $_{t-1}$ & $(0.0558)$ & $(0.0535)$ & $(0.0550)$ & $(0.0484)$ & $(0.0574)$ & $(0.0504)$ \\
\hline RESIL $_{\mathrm{t}-2}$ & $(0.0396)$ & $(0.0319)$ & $(0.0395)$ & $(0.0325)$ & $(0.0360)$ & $(0.0369)$ \\
\hline \multirow[t]{2}{*}{ Log(ODA) } & $0.0999 * * *$ & & & & & \\
\hline & $(0.0175)$ & & & & & \\
\hline \multirow[t]{2}{*}{ Log(NonAfTTOT) } & & & $0.126^{* * *}$ & & & \\
\hline & & & $(0.0201)$ & & & \\
\hline \multirow[t]{2}{*}{ Log(AfTINFRA) } & & & & $0.0542^{* * *}$ & & \\
\hline & & & & $(0.00695)$ & & \\
\hline \multirow[t]{2}{*}{ Log(AfTPROD) } & & & & & $0.0830 * * *$ & \\
\hline & & & & & $(0.00925)$ & \\
\hline FINPOL & $(0.182)$ & $(0.170)$ & $(0.185)$ & $(0.156)$ & $(0.173)$ & $(0.212)$ \\
\hline \multirow[t]{2}{*}{${\text { [FINPOL }]^{2}}^{2}$} & $0.496^{* * *}$ & $0.864^{* * *}$ & $0.444^{* *}$ & $0.730^{* * *}$ & $0.568^{* * *}$ & $0.442^{* *}$ \\
\hline & $(0.178)$ & $(0.157)$ & $(0.180)$ & $(0.147)$ & $(0.179)$ & $(0.209)$ \\
\hline \multirow[t]{2}{*}{$\log ($ GDPC) } & 0.0224 & -0.000571 & $0.0449 *$ & 0.00205 & 0.00947 & -0.00980 \\
\hline & $(0.0233)$ & $(0.0176)$ & $(0.0244)$ & $(0.0143)$ & $(0.0170)$ & $(0.0157)$ \\
\hline \multirow[t]{2}{*}{ Constant } & $-0.876^{*}$ & 0.310 & $-1.168^{* *}$ & 0.264 & 0.886 & 0.198 \\
\hline & $(0.501)$ & $(0.520)$ & $(0.544)$ & $(0.446)$ & $(0.559)$ & $(0.492)$ \\
\hline
\end{tabular}




\begin{tabular}{|c|c|c|c|c|c|c|}
\hline Observations - Countries & $327-93$ & $327-93$ & $327-93$ & $327-93$ & $327-93$ & $325-93$ \\
\hline Number of Instruments & 51 & 51 & 51 & 51 & 51 & 0.0047 \\
\hline AR1 (P-Value) & 0.0007 & 0.0049 & 0.0005 & 0.0047 & 0.0028 \\
\hline AR2 (P-Value) & 0.3339 & 0.6375 & 0.2480 & 0.6101 & 0.3982 \\
\hline OID (P-Value) & 0.6788 & 0.8576 & 0.8469 & 0.6853 & 0.9189 & 0.7071 \\
\hline
\end{tabular}

Note: ${ }^{*}$-value $<0.1$; **p-value $<0.05$; ***-value $<0.01$. Robust standard errors are in parenthesis. The aid variables and the variables "OPEN", "TOTREV", "FINPOL", the squared of the latter, and "GDPC" bave been treated as endogenous. Time dummies bave been included in the regressions. The latter have used a maximum of 3 lags of the dependent variable as instruments, and 2 lags of endogenous variables as instruments. 
Results in Table 3 confirm the findings in Table 2 concerning the effect of development aid variables on export resilience. We find that at the $1 \%$ level, all aid variables hold positive and significant coefficients. NonAfT flows appear to exert a higher positive effect on export resilience than AfT flows. Among AfT components, AfT for productive capacities exert, in terms of magnitude, the highest positive effect on export resilience. This is followed by AfT for economic infrastructure and then by AfT for trade policy and regulation. A 1 percentage increase in total development aid flows generates a rise in export resilience by $0.1 \%$. A 1 percentage rise in total AfT flows induces a 0.07 percentage increase in the values of the index of export resilience. An increase in NonAfT flows by 1 percentage is associated with a rise in the index of export resilience by 0.126 . The magnitude of the effect of each of the three components of total AfT flows on export resilience amounts respectively to 0.083 for AfT for productive capacities, 0.054 for AfT for economic infrastructure and 0.027 for AfT related to trade policy and regulation. On another note, across all columns of Table 3, the real per capita income does not affect significantly export resilience at the $10 \%$ level. In column [1] of Table 3, trade policy liberalization does not influence significantly export resilience at the $10 \%$ level, while in the other columns of the Table, the indicator of trade policy displays alternatively non-significant coefficient (see column [6]), and negative and significant coefficients (at least at the 10\% level). Financial openness exerts a nonlinear effect - in the form of a U-curve - on export resilience. In particular, financial openness reduces export resilience when its level is lower than $0.56=0.557 /(2 * 0.496)$, and enhances export resilience for higher degrees of financial openness. This finding confirms the fact that high levels of financial openness generate greater export resilience. 
Table 4: Effect of development aid on export resilience through the productive capacities channel Estimator: Two-Step System GMM

\begin{tabular}{|c|c|c|c|c|c|c|c|c|}
\hline Variables & RESIL & RESIL & RESIL & RESIL & RESIL & RESIL & RESIL & RESIL \\
\hline & (1) & (2) & (3) & (4) & (5) & (6) & (7) & (8) \\
\hline \multirow[t]{2}{*}{ RESIL $_{\mathrm{t}-1}$} & $1.015^{* * *}$ & $1.032 * * *$ & $0.992^{* * *}$ & $0.883^{* * *}$ & $0.994 * * *$ & $0.883^{* * *}$ & $0.924 * * *$ & $1.023 * * *$ \\
\hline & $(0.0450)$ & $(0.0450)$ & $(0.0403)$ & $(0.0360)$ & $(0.0376)$ & $(0.0346)$ & $(0.0419)$ & $(0.0330)$ \\
\hline \multirow[t]{2}{*}{ RESIL $_{t-2}$} & $-0.326^{* * *}$ & $-0.348^{* * *}$ & $-0.344 * * *$ & $-0.234 * * *$ & $-0.347 * * *$ & $-0.231 * * *$ & $-0.252^{* * *}$ & $-0.342^{* * *}$ \\
\hline & $(0.0318)$ & $(0.0341)$ & $(0.0291)$ & $(0.0238)$ & $(0.0268)$ & $(0.0249)$ & $(0.0275)$ & $(0.0284)$ \\
\hline \multirow[t]{2}{*}{$\log (\mathrm{ODA})$} & & $0.119^{* * *}$ & $1.133^{* * *}$ & & & & & \\
\hline & & $(0.0193)$ & $(0.182)$ & & & & & \\
\hline \multirow[t]{2}{*}{$\log (\mathrm{PCI})$} & $0.270^{* *}$ & $-0.525^{* * *}$ & $6.144^{* * *}$ & $4.833^{* * *}$ & $4.700 * * *$ & $3.272^{* * *}$ & $3.473^{* * *}$ & 0.118 \\
\hline & $(0.129)$ & $(0.160)$ & $(1.073)$ & $(0.904)$ & $(1.144)$ & $(0.835)$ & $(0.658)$ & $(0.294)$ \\
\hline \multirow[t]{2}{*}[\operatorname{Log}(\mathrm{ODA})]{$^{*}[\log (\mathrm{PCI})]$} & & & $-0.322^{* * *}$ & & & & & \\
\hline & & & $(0.0544)$ & & & & & \\
\hline \multirow[t]{2}{*}{ Log(AfTTOT) } & & & & $1.107 * * *$ & & & & \\
\hline & & & & $(0.157)$ & & & & \\
\hline \multirow[t]{2}{*}[\mathrm{Log}(\mathrm{AfTTOT})]{$^{*}[\log (\mathrm{PCI})]$} & & & & $-0.310 * * *$ & & & & \\
\hline & & & & $(0.0480)$ & & & & \\
\hline \multirow[t]{2}{*}{ Log(NonAfTTOT) } & & & & & $0.890 * * *$ & & & \\
\hline & & & & & $(0.189)$ & & & \\
\hline \multirow[t]{2}{*}[\operatorname{Log}(\operatorname{NonAfTTOT})]{$^{*}[\log (\mathrm{PCI})]$} & & & & & $-0.248^{* * *}$ & & & \\
\hline & & & & & $(0.0574)$ & & & \\
\hline \multirow[t]{2}{*}{ Log(AfTINFRA) } & & & & & & $0.780^{* * *}$ & & \\
\hline & & & & & & $(0.157)$ & & \\
\hline \multirow[t]{2}{*}{$\log (\text { AfTINFRA) }]^{*}[\log (\mathrm{PCI})]$} & & & & & & $-0.218^{* * *}$ & & \\
\hline & & & & & & $(0.0469)$ & & \\
\hline \multirow[t]{2}{*}{ Log(AfTPROD) } & & & & & & & $0.839 * * *$ & \\
\hline & & & & & & & $(0.122)$ & \\
\hline \multirow[t]{2}{*}{$\log ($ AfTPROD) $] *[\log (\mathrm{PCI})]$} & & & & & & & $-0.236^{* * *}$ & \\
\hline & & & & & & & $(0.0367)$ & \\
\hline Log(AfTPOL) & & & & & & & & 0.0816 \\
\hline
\end{tabular}




\begin{tabular}{|c|c|c|c|c|c|c|c|c|}
\hline & & & & & & & & $(0.0671)$ \\
\hline \multirow{2}{*}[\operatorname{Log}(\mathrm{AfTPOL})]{$^{*}[\log (\mathrm{PCI})]$} & & & & & & & & -0.0178 \\
\hline & & & & & & & & $(0.0204)$ \\
\hline \multirow[t]{2}{*}{$\log ($ GDPC) } & $-0.0414^{*}$ & $0.114^{* * *}$ & $0.0820^{* * *}$ & $0.130^{* * *}$ & $0.0730 * * *$ & $0.0762^{* * *}$ & $0.100^{* * *}$ & 0.0154 \\
\hline & $(0.0239)$ & $(0.0307)$ & $(0.0201)$ & $(0.0248)$ & $(0.0179)$ & $(0.0226)$ & $(0.0214)$ & $(0.0156)$ \\
\hline \multirow[t]{2}{*}{$\log (\mathrm{TP})$} & -0.0424 & -0.0635 & -0.0636 & -0.0722 & -0.0282 & -0.107 & -0.0811 & 0.0314 \\
\hline & $(0.109)$ & $(0.127)$ & $(0.0980)$ & $(0.0774)$ & $(0.0903)$ & $(0.0786)$ & $(0.0980)$ & $(0.0808)$ \\
\hline \multirow[t]{2}{*}{ FINPOL } & $-0.574 * * *$ & -0.147 & $-0.643 * * *$ & $-0.692 * * *$ & $-0.665 * * *$ & $-0.584 * * *$ & $-0.600 * * *$ & $-0.511 * * *$ \\
\hline & $(0.187)$ & $(0.200)$ & $(0.153)$ & $(0.150)$ & $(0.152)$ & $(0.134)$ & $(0.165)$ & $(0.173)$ \\
\hline \multirow[t]{2}{*}{ FINPOL $^{2}$} & $0.590 * * *$ & 0.193 & $0.615^{* * *}$ & $0.603 * * *$ & $0.633^{* * *}$ & $0.563^{* * *}$ & $0.530^{* * *}$ & $0.524 * * *$ \\
\hline & $(0.169)$ & $(0.184)$ & $(0.146)$ & $(0.143)$ & $(0.148)$ & $(0.122)$ & $(0.155)$ & $(0.149)$ \\
\hline \multirow[t]{2}{*}{ Constant } & -0.331 & $-1.335^{* * *}$ & $-22.05 * * *$ & $-18.02 * * *$ & $-17.26^{* * *}$ & $-11.98^{* * *}$ & $-12.90 * * *$ & -0.825 \\
\hline & $(0.383)$ & $(0.413)$ & $(3.547)$ & $(2.864)$ & $(3.695)$ & $(2.737)$ & $(2.092)$ & $(1.025)$ \\
\hline & & & & & & & & \\
\hline Turning point of "PCI" & n.a. & n.a. & $\begin{array}{c}\text { Exponential } \\
(1.133 / 0.322) \\
=33.74\end{array}$ & $\begin{array}{c}\text { Exponential } \\
(1.107 / 0.310) \\
=35.55\end{array}$ & $\begin{array}{c}\text { Exponential } \\
(0.890 / 0.248) \\
=36.19\end{array}$ & $\begin{array}{c}\text { Exponential } \\
(0.780 / 0.218) \\
=35.8\end{array}$ & $\begin{array}{c}\text { Exponential } \\
(0.839 / 0.236) \\
=35\end{array}$ & n.a. \\
\hline Observations - Countries & $328-93$ & $325-93$ & $325-93$ & $325-93$ & $325-93$ & $325-93$ & $325-93$ & $323-93$ \\
\hline Number of Instruments & 65 & 58 & 65 & 65 & 65 & 65 & 65 & 65 \\
\hline AR1 (P-Value) & 0.0029 & 0.0011 & 0.0015 & 0.0055 & 0.0014 & 0.0065 & 0.0024 & 0.0032 \\
\hline AR2 (P-Value) & 0.5261 & 0.1924 & 0.4515 & 0.4872 & 0.3846 & 0.5351 & 0.2909 & 0.5062 \\
\hline OID (P-Value) & 0.1259 & 0.6573 & 0.2312 & 0.4664 & 0.2354 & 0.6645 & 0.2999 & 0.3264 \\
\hline
\end{tabular}

Note: *p-value $<0.1$; **-value $<0.05$; ***-value $<0.01$. Robust standard errors are in parenthesis. The aid variables and the variables "PCI", "OPEN", "TOTREV", "FINPOL", the squared of the latter, and "GDPC" have been treated as endogenous. Time dummies have been included in the regressions. The latter have used a maximum of 3 lags of the dependent variable as instruments, and 2 lags of endogenous variables as instruments. 
Turning to estimates in Table 4, we note from column [1] of this Table that at the 5\% level, the development of the overall productive capacities exerts a positive effect on export resilience (the coefficient of "PCI" is positive and significant at the 5\% level). A 1 percentage increase in the index of productive capacities is associated with a 0.27 percentage increase in the values of the index of export resilience. From column [2], we note that both total development aid and the index of overall productive capacities variables have significant coefficients at the $1 \%$ level. However, the coefficient of the variable "PCI" (in Logs) becomes negative, while the coefficient of "ODA" (in Logs) remains positive. These results in columns [1] and [2] of Table 4 suggest the existence of an interaction between these two variables in influencing export resilience. This can also signify that the effect of total development aid on export resilience does not work only through the channel of productive capacities. There are likely other channels than the productive capacities (such as the real exchange rate volatility - as mentioned in section 2) through which development aid can influence export resilience. These channels would need to be investigated in another future research.

We now consider results in the other columns (i.e., from column [3] to [8]) of Table 4. Starting with estimates in column [8], we observe that neither the coefficient of the variable "AfTPOL" nor the coefficient of the interaction variable ("[Log(AfTPOL) $]^{*}[\log (\mathrm{PCI})]^{\prime)}$ are significant at the conventional significance levels. We, therefore, conclude that AfT interventions for trade policy and regulation and productive capacities do not jointly influence export resilience. Meanwhile, we obtain from estimates in columns [3] to [7] that development aid variables hold positive and significant coefficients (at the $1 \%$ level), while the interaction terms of the interaction between each aid variable and the indicator of overall productive capacities are all negative and significant at the $1 \%$ level. Taking together the estimates concerning the relevant aid variable and the interaction term in each of the columns [3] to [7], we can conclude that the magnitude of the effect of development aid (either total development aid, its two components, or AfT for economic infrastructure and AfT for productive capacities) on export resilience decreases as countries' level of productive capacities increases, and may eventually become negative for countries with a high level of productive capacities. In other words, these five development aid variables exert their highest (magnitude of the) positive effect on export resilience in countries with the lowest degree of productive capacities (e.g., poor countries). Hence, there is a turning point for the variable "PCI" beyond which the total effect of the relevant aid variable on export resilience becomes negative. The values of this turning point of "PCI" are computed and reported at the bottom of Table 4. These values are $33.74 ; 35.55 ; 36.2 ; 35.8$ and 35 when the relevant aid variable is respectively total development aid, AfT, NonAfT, AfT for economic infrastructure, and AfT for productive capacities. As per Appendix 2, values of "PCI" range between 15.4 and 37.3, interval that contains all values of turning points of "PCI" reported in Table 4. On the basis of these outcomes, we conclude that development aid enhances export resilience in countries that have low levels of productive capacities, and the lower the degree of productive capacities, the greater is the magnitude of the positive effect of development aid variables on export resilience (development aid variables being measured here by total development aid, its two components, or AfT for economic infrastructure and AfT for productive capacities).

Results related to control variables in Table 4 show that at the $5 \%$ level, the real per capita income tends to be positively associated with export resilience, while there is no significant effect 
of trade policy on export resilience. The estimates also confirm the existence of a non-linear effect of financial openness on export resilience. 
Table 5: Robustness check analysis on the effect of development aid on export resilience Estimator: Two-Step System GMM

\begin{tabular}{|c|c|c|c|c|c|c|}
\hline Variables & RESIL & RESIL & RESIL & RESIL & RESIL & RESIL \\
\hline & $(1)$ & (2) & (3) & (4) & $(5)$ & (6) \\
\hline \multirow[t]{2}{*}{ RESIL $_{\mathrm{t}-1}$} & $0.861 * * *$ & $0.761 * * *$ & $0.854 * * *$ & $0.773^{* * *}$ & $0.756^{* * *}$ & $0.816^{* * *}$ \\
\hline & $(0.0559)$ & $(0.0553)$ & $(0.0581)$ & $(0.0535)$ & $(0.0534)$ & $(0.0591)$ \\
\hline \multirow[t]{2}{*}{ RESIL $_{\mathrm{t}-2}$} & $-0.273 * * *$ & $-0.182^{* * *}$ & $-0.279 * * *$ & $-0.179 * * *$ & $-0.198^{* * *}$ & $-0.283 * * *$ \\
\hline & $(0.0419)$ & $(0.0350)$ & $(0.0434)$ & $(0.0357)$ & $(0.0359)$ & $(0.0373)$ \\
\hline \multirow[t]{2}{*}{$\log (\mathrm{ODA})$} & $0.0844^{* * *}$ & & & & & \\
\hline & $(0.0178)$ & & & & & \\
\hline \multirow[t]{2}{*}{ Log(AfTTOT) } & & $0.0742^{* * *}$ & & & & \\
\hline & & $(0.00921)$ & & & & \\
\hline \multirow[t]{2}{*}{ Log(NonAfTTOT) } & & & $0.107 * * *$ & & & \\
\hline & & & $(0.0221)$ & & & \\
\hline \multirow{2}{*}{ Log(AfTINFRA) } & & & & $0.0552^{* * *}$ & & \\
\hline & & & & $(0.00620)$ & & \\
\hline \multirow[t]{2}{*}{ Log(AfTPROD) } & & & & & $0.0736^{* * *}$ & \\
\hline & & & & & $(0.00832)$ & \\
\hline \multirow[t]{2}{*}{ Log(AfTPOL) } & & & & & & $0.0358 * * *$ \\
\hline & & & & & & $(0.00805)$ \\
\hline \multirow[t]{2}{*}{$\log (\mathrm{TP})$} & -0.122 & $-0.261 *$ & -0.239 & $-0.212^{*}$ & $-0.374 * * *$ & -0.149 \\
\hline & $(0.184)$ & $(0.149)$ & $(0.190)$ & $(0.118)$ & $(0.138)$ & $(0.129)$ \\
\hline \multirow[t]{2}{*}{ FINPOL } & $-0.471 * *$ & $-0.913 * * *$ & $-0.411 * *$ & $-0.622 * * *$ & $-0.794 * * *$ & $-0.610 * * *$ \\
\hline & $(0.188)$ & $(0.153)$ & $(0.196)$ & $(0.143)$ & $(0.148)$ & $(0.186)$ \\
\hline \multirow[t]{2}{*}{ FINPOL $^{2}$} & $0.442^{* *}$ & $0.922^{* * *}$ & $0.369^{* *}$ & $0.652^{* * *}$ & $0.754 * * *$ & $0.599 * * *$ \\
\hline & $(0.176)$ & $(0.144)$ & $(0.181)$ & $(0.135)$ & $(0.157)$ & $(0.186)$ \\
\hline \multirow[t]{2}{*}{$\log ($ GDPC) } & 0.0210 & 0.0122 & $0.0516^{* *}$ & 0.0102 & 0.0252 & 0.00747 \\
\hline & $(0.0238)$ & $(0.0197)$ & $(0.0248)$ & $(0.0153)$ & $(0.0172)$ & $(0.0158)$ \\
\hline \multirow[t]{2}{*}{ Constant } & $-1.285^{* * *}$ & -0.154 & $-1.457 * * *$ & -0.0738 & 0.209 & 0.125 \\
\hline & $(0.472)$ & $(0.490)$ & $(0.476)$ & $(0.403)$ & $(0.491)$ & $(0.483)$ \\
\hline
\end{tabular}




\begin{tabular}{|c|c|c|c|c|c|c|}
\hline Observations - Countries & $312-89$ & $312-89$ & $312-89$ & $312-89$ & $312-89$ & $310-89$ \\
\hline Number of Instruments & 51 & 51 & 51 & 51 & 51 & 51 \\
\hline AR1 (P-Value) & 0.0013 & 0.0093 & 0.0009 & 0.0076 & 0.0043 \\
\hline AR2 (P-Value) & 0.6923 & 0.7955 & 0.5684 & 0.8534 & 0.9597 & 0.0050 \\
\hline OID (P-Value) & 0.6074 & 0.6293 & 0.8138 & 0.5669 & 0.4975 & 0.5673 \\
\hline
\end{tabular}

Note: ${ }^{*}$-value $<0.1$; ${ }^{* *}$-value $<0.05$; ***-value $<0.01$. Robust standard errors are in parenthesis. The aid variables and the variables "OPEN", "TOTREV", "FINPOL", the squared of the latter, and "GDPC" bave been treated as endogenous. Time dummies have been included in the regressions. The latter have used a maximum of 3 lags of the dependent variable as instruments, and 2 lags of endogenous variables as instruments. 
Table 6: Robustness check analysis on the effect of development aid on export resilience through the productive capacities channel Estimator: Two-Step System GMM

\begin{tabular}{|c|c|c|c|c|c|c|}
\hline Variables & RESIL & RESIL & RESIL & RESIL & RESIL & RESIL \\
\hline RESIL $_{\mathrm{t}-1}$ & $(0.0381)$ & $(0.0299)$ & $(0.0360)$ & $(0.0338)$ & $(0.0430)$ & $(0.0392)$ \\
\hline RESIL $_{\mathrm{t}-2}$ & $(0.0316)$ & $(0.0247)$ & $(0.0282)$ & $(0.0266)$ & $(0.0278)$ & $(0.0256)$ \\
\hline \multirow[t]{2}{*}{$\log (\mathrm{ODA})$} & $0.974 * * *$ & & & & & \\
\hline & $(0.147)$ & & & & & \\
\hline$[\log (\mathrm{ODA})]^{*}[\log (\mathrm{PCI})]$ & $-0.275^{* * *}$ & & & & & \\
\hline \multirow[t]{2}{*}{ Log(AfTTOT) } & & $0.962^{* * *}$ & & & & \\
\hline & & $(0.159)$ & & & & \\
\hline \multirow{2}{*}{$\log (\text { AfTTOT) }]^{*}[\log (\mathrm{PCI})]$} & & $-0.266^{* * *}$ & & & & \\
\hline & & $(0.0487)$ & & & & \\
\hline \multirow[t]{2}{*}{ Log(NonAfTTOT) } & & & $0.736^{* * *}$ & & & \\
\hline & & & $(0.153)$ & & & \\
\hline$[\log ($ AfTINFRA) $] *[\log (\mathrm{PCI})]$ & & & & $(0.0388)$ & & \\
\hline \multirow[t]{2}{*}{ Log(AfTPROD) } & & & & & $0.926^{* * *}$ & \\
\hline & & & & & $(0.122)$ & \\
\hline \multirow[t]{2}{*}{$\log (\text { AfTPROD) }]^{*}[\log (\mathrm{PCI})]$} & & & & & $-0.263 * * *$ & \\
\hline & & & & & $(0.0361)$ & \\
\hline \multirow[t]{2}{*}{ Log(AfTPOL) } & & & & & & $0.191^{* * *}$ \\
\hline & & & & & & $(0.0383)$ \\
\hline$\left[\log (\text { AfTPOL) }]^{*}[\log (\mathrm{PCI})]\right.$ & & & & & & $-0.0516^{* * *}$ \\
\hline
\end{tabular}




\begin{tabular}{|c|c|c|c|c|c|c|}
\hline & & & & & & $(0.0125)$ \\
\hline $\log (\mathrm{PCI})$ & $5.380 * * *$ & $4.152^{* * *}$ & $3.926 * * *$ & $3.384 * * *$ & $4.094 * * *$ & $0.646^{* * *}$ \\
\hline $\log (\mathrm{TP})$ & -0.112 & -0.107 & -0.0589 & $-0.194^{* *}$ & -0.117 & 0.0453 \\
\hline \multirow[t]{2}{*}{ FINPOL } & $-0.786 * * *$ & $-0.666^{* * *}$ & $-0.772^{* * *}$ & $-0.562 * * *$ & $-0.599 * * *$ & $-0.428^{* * *}$ \\
\hline & $(0.132)$ & $(0.135)$ & $(0.126)$ & $(0.118)$ & $(0.144)$ & $(0.120)$ \\
\hline${\text { [FINPOL }]^{2}}^{2}$ & $0.736^{* * *}$ & $0.587 * * *$ & $0.702^{* * *}$ & $0.567 * * *$ & $0.528^{* * *}$ & $0.408^{* * *}$ \\
\hline Log(GDPC) & $(0.0192)$ & $(0.0233)$ & $(0.0173)$ & $(0.0171)$ & $(0.0201)$ & $(0.0121)$ \\
\hline \multirow[t]{2}{*}{ Constant } & $-19.04 * * *$ & $-15.65^{* * *}$ & $-14.57 * * *$ & $-11.88^{* * *}$ & $-14.79 * * *$ & $-2.548^{* * *}$ \\
\hline & $(2.821)$ & $(2.890)$ & $(2.937)$ & $(2.195)$ & $(2.004)$ & $(0.677)$ \\
\hline Turning point of "PCI" & $\begin{array}{c}\text { Exponential } \\
(0.974 / 0.275)= \\
34.53\end{array}$ & $\begin{array}{c}\text { Exponential } \\
(0.962 / 0.266)= \\
37.21\end{array}$ & $\begin{array}{c}\text { Exponential } \\
(0.736 / 0.202)= \\
38.23\end{array}$ & $\begin{array}{c}\text { Exponential } \\
(0.775 / 0.216)= \\
36.16\end{array}$ & $\begin{array}{c}\text { Exponential } \\
(0.926 / 0.263)= \\
33.82\end{array}$ & $\begin{array}{c}\text { Exponential } \\
(0.191 / 0.0516) \\
=40.5\end{array}$ \\
\hline OID (P-Value) & 0.2417 & 0.4510 & 0.2234 & 0.5310 & 0.3693 & 0.2752 \\
\hline
\end{tabular}

Note: *p-value $<0.1$; **p-value $<0.05$; ***p-value $<0.01$. Robust standard errors are in parenthesis. The aid variables and the variables "PCI", "OPEN", "TOTREV", "FINPOL", the squared of the latter, and "GDPC" have been treated as endogenous. Time dummies have been included in the regressions. The latter have used a maximum of 3 lags of the dependent variable as instruments, and 2 lags of endogenous variables as instruments. 
Outcomes in Tables 5 and 6 (based on the sample without outliers) help check the robustness of findings reported respectively in Tables 3 and 4 . We note that outcomes reported in Table 5 are similar to those in Table 3, including in terms of statistical significance of estimates. In particular, coefficients of aid variables in Table 5 are close to the estimates of aid variables reported in Table 3. Thus, we conclude that all aid variables, including total development aid flows, AfT flows (including its three components) and NonAfT flows exert a positive effect on export resilience, with the effect of NonAfT flows on export resilience being slightly higher than that of AfT flows. Additionally, among the components of AfT flows, AfT for productive capacities appears to exert the highest positive effect on export resilience, followed by AfT for economic infrastructure and AfT for trade policy and regulations.

Findings in Table 6 are in line with those in Table 4, with the exception of the effect of AfT related to trade policy and regulation. Specially, in all columns of this Table, the coefficient of all aid variables are positive and significant at the $1 \%$ level, and the interaction variable between each aid variable and the indicator of overall productive capacities always holds a negative and significant (at the 1\% level) coefficient. We conclude that the magnitude of the positive effect of development aid (whatever the aid variable considered) on export resilience decreases as the level of productive capacities rises, and may decline for very high levels of productive capacities. The turning point of "PCI" above which this effect may become negative is given by 34.53 ; 37.21; 38.23 ; 36.16; 33.82; and 40.5 when the relevant aid variable is respectively total development aid, AfT, NonAfT, AfT for economic infrastructure, AfT for productive capacities, and AfT for trade policy and regulation. It is noteworthy that values of "PCI" in the full sample excluding the four country-outliers mentioned above, still range from 15.4 to 37.3 . The only value among the turning points of "PCI" reported in Table 6 that exceeds the maximum value of "PCI" in the sample (including excluding outlier-countries) is 40.5 . We conclude for all aid variables that the lower the level of productive capacities, the higher is the magnitude of the positive effect of a relevant aid variable on export resilience. In other words, countries with low levels of overall productive capacities enjoy a higher positive effect of development aid (whatever the aid variable considered) on export resilience than countries with relatively higher levels of productive capacities. This positive effect of development aid on export resilience may turn out to be negative for very high levels of productive capacities, notably for the following aid variables: total development aid, AfT, NonAfT, AfT for economic infrastructure and AfT for productive capacities. The effect of AfT for trade policy and regulation on export resilience is always positive for every levels of productive capacities, but its magnitude falls as the level of productive capacities increases.

Results associated with control variables in Table 6 are consistent with those in Table 5.

\section{Conclusion}

The COVID-19 health crisis, like other major crises (e.g., the 2008 financial crises) have severely impacted trade flows, in particular countries' exports. With the assistance of international organizations, countries have been exploring ways and means to recover from the pandemic, and strengthening the resilience of value chains, and trade flows to future shocks. For example, in that context, the theme of the 2021 W'TO Public Forum, which is expected to take place on 28-30 September 2021, is "Trade Beyond COVID-19: Building Resilience". The current paper aims to contribute to this debate by shedding light on the relationship between development aid flows, in 
particular AfT flows and export resilience. The paper argues that productive capacities represent the main channel through which development aid can influence export resilience.

The analysis has relied on a sample of 93 aid recipient countries over the period 2000-2018. Results suggest that total development aid flows (including AfT flows and NonAfT flows) contribute to enhancing export resilience in recipient countries, with the effect of NonAfT flows being higher than that of AfT flows. Additionally, all components of AfT flows, including AfT flows for economic infrastructure, AfT flows for productive capacities, and AfT flows for trade policy and regulation influence positively export resilience, with AfT flows for productive capacities exerting the highest positive effect on export resilience, followed by AfT for economic infrastructure and AfT for trade policy and regulation.

These findings show that if they were to help developing countries build the resilience of their exports, donor-countries should allocate higher aid flows to countries with low levels of productive capacities. These countries include less advanced developing countries, notably poorest countries (i.e., LDCs), as they are not only those in most need of aid flows (given their limited financial resources to address their huge development challenges), but also those that experience low levels of productive capacities.

An avenue for future research can be not to develop other measures of export resilience, but also to explore other possible channels (apart from the productive capacities) through which development aid can influence export resilience. 
-Appendix 1: Definition and Source of variables

\begin{tabular}{|c|c|c|}
\hline Variables & Definition & Source \\
\hline RESIL & Indicator of Export Resilience & Author's computation - see Section 3 \\
\hline PCI & $\begin{array}{l}\text { The overall Productive Capacity Index. It measures the level of productive capacities } \\
\text { along three pillars: "the productive resources, entrepreneurial capabilities and } \\
\text { production linkages which together determine the capacity of a country to produce } \\
\text { goods and services and enable it to grow and develop" (UNCTAD, 2006). } \\
\text { It is computed as a geometric average of eight domains or categories, namely, } \\
\text { Information communication and technologies (ICTs), structural change, natural } \\
\text { capital, human capital, energy, transport, the private sector and institutions. Each } \\
\text { category index is obtained from the principal components extracted from the } \\
\text { underlying indicators, weighted by their capacity to explain the variance of the original } \\
\text { data. The category indices are normalized into } 0-100 \text { intervals. }\end{array}$ & $\begin{array}{c}\text { United Nations Conference on Trade and } \\
\text { Development (UNCTAD) Statistics portal: } \\
\frac{\text { https://unctadstat.unctad.org/wds/ReportFolders }}{\text { /reportFolders.aspx }} \\
\text { See UNCTAD (2020) for a complete description } \\
\text { of the methodology used to compute the indicator } \\
\text { "PCI". }\end{array}$ \\
\hline $\begin{array}{c}\text { ODA, } \\
\text { AfTTOT, } \\
\text { AfTINFRA, } \\
\text { AfTPROD, } \\
\text { AfTPOL }\end{array}$ & $\begin{array}{l}\text { "ODA" is the real gross disbursements of total Official Development Assistance } \\
\text { (ODA) expressed in constant prices 2018, US Dollar. } \\
\text { "AfTTOT" is the total real gross disbursements of Aid for Trade. "AfTINFRA" is the } \\
\text { real gross disbursements of Aid for Trade allocated to the buildup of economic } \\
\text { infrastructure. "AfTPROD" is the real gross disbursements of Aid for Trade for } \\
\text { building productive capacities. } \\
\text { "AfTPOL" is the real gross disbursements of Aid allocated for trade policies and } \\
\text { regulation. All four AfT variables are expressed in constant prices 2018, US Dollar. }\end{array}$ & $\begin{array}{c}\text { Author's calculation based on data extracted from } \\
\text { the database OECD statistical database on } \\
\text { development, in particular the OECD/DAC-CRS } \\
\text { (Organization for Economic Cooperation and } \\
\text { Development/Donor Assistance Committee)- } \\
\text { Credit Reporting System (CRS). Aid for Trade } \\
\text { data cover the following three main categories (the } \\
\text { CRS Codes are in brackets): } \\
\text { Aid for Trade for Economic Infrastructure } \\
\text { ("AfTINFRA"), which includes transport and } \\
\text { storage (210), communications (220), and energy } \\
\text { generation and supply (230); } \\
\text { Aid for Trade for Building Productive Capacity } \\
\text { ("AfTPROD"), which includes banking and }\end{array}$ \\
\hline
\end{tabular}




\begin{tabular}{|c|c|c|}
\hline & & $\begin{array}{l}\text { financial services (240), business and other services } \\
\text { (250), agriculture (311), forestry (312), fishing (313), } \\
\text { industry (321), mineral resources and mining (322), } \\
\text { and tourism (332); and } \\
\text { Aid for Trade policy and regulations ("AfTPOL"), } \\
\text { which includes trade policy and regulations and } \\
\text { trade-related adjustment (331). }\end{array}$ \\
\hline NonAfTTOT & $\begin{array}{l}\text { This is the measure of the development aid allocated to other sectors in the economy } \\
\text { than the trade sector. It has been computed as the difference between the gross } \\
\text { disbursements of total ODA and the gross disbursements of total Aid for Trade (both } \\
\text { being expressed in constant prices 2018, US Dollar). }\end{array}$ & $\begin{array}{l}\text { Author's calculation based on data extracting from } \\
\text { the OECD/DAC-CRS database. }\end{array}$ \\
\hline EXPORT & Exports of goods and services (constant 2010 US $\$$ ) & World Bank Indicators (WDI) \\
\hline EVI & $\begin{array}{l}\text { This is indicator of structural economic vulnerability, also referred to as the Economic } \\
\text { Vulnerability Index. It has been set up at the United Nations by the Committee for } \\
\text { Development Policy (CDP), and used by the latter as one of the criteria for identifying } \\
\text { LDCs. It has been computed on a retrospective basis for } 145 \text { developing countries } \\
\text { (including } 48 \text { LDCs) by the "Fondation pour les Etudes et Recherches sur le } \\
\text { Developpement International (FERDI)". The EVI has been computed as the simple } \\
\text { arithmetic average of two sub-indexes, namely the intensity of exposure to shocks } \\
\text { (exposure sub-index) and the intensity of exogenous shocks (shocks sub-index). These } \\
\text { two sub-indexes have been calculated using a weighted average of different } \\
\text { component indexes, with the sum of components' weights equals } 1 \text { so that the values } \\
\text { of EVI range between } 0 \text { and } 100 \text {. For further details on the computation of the EVI, } \\
\text { see for example Feindouno and Goujon (2016). }\end{array}$ & $\begin{array}{l}\text { Data on EVI is extracted from the database of the } \\
\text { Fondation pour les Etudes et Recherches sur le } \\
\text { Developpement International (FERDI) - see } \\
\text { online at: https://ferdi.fr/donnees/un-indicateur- } \\
\text { de-vulnerabilite-economique-evi-retrospectif }\end{array}$ \\
\hline TOTREV & $\begin{array}{l}\text { This is the share of total public revenue (excluding grants and social contributions) in } \\
\text { GDP. This variable is not expressed in percentage. }\end{array}$ & $\begin{array}{c}\text { Public Revenue Dataset developed by the United } \\
\text { Nations University World Institute for } \\
\text { Development Economics Research (UNU- } \\
\text { WIDER). See online: } \\
\text { https://www.wider.unu.edu/project/government- } \\
\text { revenue-dataset }\end{array}$ \\
\hline
\end{tabular}




\begin{tabular}{|c|c|c|}
\hline OPEN & $\begin{array}{l}\text { This is the indicator of trade openness, measured by the share of sum of exports and } \\
\text { imports of goods and services in GDP. This variable is not expressed in percentage. }\end{array}$ & $\begin{array}{c}\text { Authors' calculation based on data extracted from } \\
\text { the WDI. }\end{array}$ \\
\hline GDPC & Per capita Gross Domestic Product (constant 2010 US\$). & WDI \\
\hline $\mathrm{TP}$ & $\begin{array}{l}\text { This is the indicator of trade policy, measured by the trade freedom score. The latter is } \\
\text { a component of the Economic Freedom Index. It is a composite measure of the } \\
\text { absence of tariff and non-tariff barriers that affect imports and exports of goods and } \\
\text { services. The trade freedom score is graded on a scale of } 0 \text { to } 100 \text {, with a rise in its } \\
\text { value indicating lower trade barriers, i.e., higher trade liberalization, while a decrease in } \\
\text { its value reflects rising trade protectionism. }\end{array}$ & Heritage Foundation (see Miller et al., 2019) \\
\hline FINPOL & This is the measure of financial policy, i.e., de jure financial openness. & $\begin{array}{l}\text { This index has been computed by Chinn and Ito } \\
(2006) \text { and updated in July } 2020 \text {. Its value ranges } \\
\text { between } 0 \text { and } 1 \text {. See: } \\
\text { http://web.pdx.edu/ ito/Chinn-Ito website.htm } \\
\text { For the purpose of the present study, we have } \\
\text { transformed this index by multiplying its values by } \\
\text { 100. So, its values range here between } 0 \text { and } 100 .\end{array}$ \\
\hline
\end{tabular}


Appendix 2: Descriptive statistics on variables used in the analysis

\begin{tabular}{|c|c|c|c|c|c|}
\hline Variable & Observations & Mean & Standard deviation & Minimum & Maximum \\
\hline RESIL & 327 & 0.108 & 0.252 & -0.868 & 1.443 \\
\hline EXPORT & 327 & 44200 & 87100 & 76 & 559000 \\
\hline EVI & 327 & 31.44 & 10.806 & 9.2242 & 70.045 \\
\hline ODA & 327 & 967 & 1060 & 11 & 6090 \\
\hline AfTTOT & 327 & 294 & 475 & 0.054762 & 3650 \\
\hline AfTINFRA & 327 & 182 & 331 & 0.01176 & 3110 \\
\hline AfTPROD & 327 & 107 & 179 & 0.016798 & 1890 \\
\hline AfTPOL & 325 & 5.0352 & 15.2 & 0.001103 & 248 \\
\hline NonAfTTOT & 327 & 673 & 680 & 11 & 3610 \\
\hline PCI & 325 & 26.935 & 4.787 & 15.428 & 37.281 \\
\hline TOTREV & 289 & 0.193 & 0.088 & 0.062 & 0.776 \\
\hline OPEN & 327 & 0.729 & 0.319 & 0.199 & 2.043 \\
\hline TP & 327 & 71.094 & 9.691 & 32.733 & 89.000 \\
\hline FINPOL & 327 & 0.396 & 0.327 & 0.000 & 1.000 \\
\hline GDPC & 327 & 3960.701 & 3889.988 & 212.472 & 19111.660 \\
\hline
\end{tabular}

Note: The variables "EXPORT", "ODA", "AfTTOT", "AfTINFRA", "AfTPROD", "AfTPOL" and "NonAfTTOT" are expressed in US\$ million.

Appendix 3: List of countries contained in the full sample

\begin{tabular}{|c|c|c|}
\hline \multicolumn{3}{|c|}{ Full sample } \\
\hline Algeria & Gabon & Mozambique \\
\hline Angola & Gambia, The & Myanmar \\
\hline Argentina & Georgia & Namibia \\
\hline Armenia & Ghana & Nepal \\
\hline Bangladesh & Guatemala & Nicaragua \\
\hline Belize & Guinea & Niger \\
\hline Benin & Guinea-Bissau & Nigeria \\
\hline Bhutan & Haiti & Oman \\
\hline Bolivia & Honduras & Pakistan \\
\hline Bosnia and Herzegovina & India & Panama \\
\hline Brazil & Indonesia & Paraguay \\
\hline Burkina Faso & Iran, Islamic Rep. & Peru \\
\hline Burundi & Jamaica & Philippines \\
\hline Cabo Verde & Jordan & Rwanda \\
\hline Cambodia & Kazakhstan & Senegal \\
\hline Cameroon & Kenya & Sierra Leone \\
\hline Central African Republic & Kyrgyz Republic & South Africa \\
\hline Chad & Lao PDR & Sri Lanka \\
\hline Chile & Lebanon & Sudan \\
\hline Colombia & Lesotho & Tanzania \\
\hline Comoros & Liberia & Thailand \\
\hline Congo, Dem. Rep. & Libya & Togo \\
\hline Congo, Rep. & Madagascar & Tunisia \\
\hline Costa Rica & Malawi & Turkey \\
\hline Cote d'Ivoire & Malaysia & Uganda \\
\hline
\end{tabular}




\begin{tabular}{|c|c|c|}
\hline Dominican Republic & Mali & Uruguay \\
\hline Ecuador & Mauritania & Uzbekistan \\
\hline Egypt, Arab Rep. & Mauritius & Venezuela, RB \\
\hline El Salvador & Mexico & Vietnam \\
\hline Equatorial Guinea & Mongolia & Zambia \\
\hline Eswatini & Morocco & Zimbabwe \\
\hline
\end{tabular}

\section{References}

Acemoglu, D., and Zilibotti, F. (1997). Was prometheus unbound by chance? Risk, diversification, and growth. Journal of Political Economy, 105(4), 709-51.

Acemoglu, D., Johnson, S., Robinson, J., and Taicharoen, Y. (2003). Institutional causes, macroeconomic symptoms: volatility, crises and growth. Journal of Monetary Economics, 50(1), $49-123$.

Aditya, A., and Acharyya, R. (2015). Trade liberalization and export diversification. International Review of Economics \& Finance, 39, 390-410.

Agenor, P. R. (2003). Benefits and costs of international financial integration: Theory and facts. The World Economy, 26(8), 1089-1118.

Aghion, P., Akcigit, U., and Howitt, P. (2015). The Schumpeterian Growth Paradigm. Annual Review of Economics, 7(1), 557-575.

Aghion, P., Farhi, E., and Kharroubi, E. (2019). Monetary Policy, Product Market Competition and Growth. Economica, 86 (343), 431-470.

Aguirre, A., and Calderón, C. (2005). Real exchange rate misalignments and economic performance. Central Bank of Chile working papers 315, Central Bank of Chile.

Al-Abri, A., and Baghestani, H. (2015). Foreign investment and real exchange rate volatility in emerging Asian countries. Journal of Asian Economics, 37, 34-47.

Amiti, M., and Weinstein, D.E. (2011). Exports and Financial Shocks. The Quarterly Journal of Economics, 126(4), 1841-1877.

Anderson, J.E., and van Wincoop, E. (2001). Gravity with gravitas: A solution to the border puzzleí, National Bureau of Economic Research Working Paper 8079, Cambridge, MA.

Andersson, M., and Johansson, S. (2010). Human capital and the structure of regional export flows. Technology in Society, 32(3), 230-240

Anderton, R., Di Lupidio, B., and Jarmulska, B. (2020). The impact of product market regulation on productivity through firm churning: Evidence from European countries. Economic Modelling, 91, 487-501. 
Andrade da Silva, J., and Cernat, L. (2012). Coping with loss: the impact of natural disasters on developing countries' trade flows. Directorate General for Trade - Chief Economist Notes 20121, Directorate General for Trade, European Commission.

Andrews, D., and Saia, A. (2017). Coping with Creative Destruction: Reducing the Costs of Firm Exit. OECD Economics Department Working Papers No. 1353. OECD Publishing, OECD, Paris.

Antoniak, A., Bartoszek, K., Borino, F., Bzymek, K., Fulara, J., Grześkowiak, J., Kierzkowski, T., Kurek, D., Moumouni, A. B., Mrówczyński, K., Rollo, V., Wójcik, M. (2021). Report on the Situation of Micro, Small and Medium-Sized Enterprises in the year 2020 Special topic: Impact of COVID-19 on the SME sector. International Trade Centre, and Bank Pekao, Warsaw, 2021.

Ariss, R. T. (2016). Legal Systems, Capital Structure, and Debt Maturity in Developing Countries. Corporate Governance, 24(2), 130-144.

Asheghian, P., and Saidi, R. (2002). Commodity Concentration and Export Earning Instability: The Case of Venezuela. Development Policy Review, 17(4), 419-427.

Athukorola, P. C. (2000). Manufacturing exports and terms of trade of developing countries: evidence from Sri Lanka. Journal of Development Studies, 36(5), 89-104.

Auboin, M., and Meier-Ewert, M. (2003). Improving the Availability of Trade Finance during Financial Crises. WTO Discussion Paper, World Trade Organization, Geneva, Switzerland. Retrieved at: https://www.wto.org/english/res_e/booksp_e/discussion_papers2 e.pdf

Bacchetta, M., Bekkers, E., Piermartini, R., Rubinova, S., Stolzenburg, V., and Xu, A. (2021). Covid-19 and Global Value Chains - A Discussion of Arguments on Value Chain Organization and the Role of the WTO. WTO Staff Working Paper ERSD-2021-3. World Trade Organization, Geneva, Switzerland.

Bahar, D., and Santos, M.A. (2018). One more resource curse: Dutch disease and export concentration. Journal of Development Economics, 132, 102-114.

Balavac, M., and Pugh, G. (2016). The link between trade openness, export diversification, institutions and output volatility in transition countries. Economic Systems, 40(2), 273-287.

Baldwin, R., and Evenett, S.J. (2020). "Introduction" in Richard Baldwin and Simon J. Evenett (eds.), Covid-10 and Trade Policy: Why Turning Inward Won't Work, CEPR Press VoxEU.org eBook, 2020.

Baldwin, R., and Tomiura, E. (2020). "Thinking ahead about the trade impact of COVID-19," Chapter 5 in Baldwin and Weder di Mauro (2020), Economics in the Time of COVID-19, a VoxEU.org eBook, CEPR Press, Centre for Economic Policy Research, London, United Kingdom.

Barkas, P., Honeck, D., and Colomer, E.R. (2020). International trade in travel and tourism services: economic impact and policy responses during the covid-19 crisis. Staff Working Paper ERSD-2020-11. 
Barlow, P., van Schalkwyk, M. CI., McKee, M., Labonté, R., and Stuckler, D. (2021). COVID-19 and the collapse of global trade: building an effective public health response. The Lancet Planetary Health, 5(2), e102-e107.

Bas, M. (2020). The effect of communication and energy services reform on manufacturing firms' innovation. Journal of Comparative Economics, 48(2), 339-362.

Bassanini, A., and Duval, R. (2007). The determinants of unemployment across OECD countries: Reassessing the role of policies and institutions. OECD Economic Studies, Vol. 2006/1.

Belhadi, A., Kamble, S., Jabbour, C. J., C., Gunasekaran, A., Ndubisi, N. O., and Venkatesh, M. (2021). Manufacturing and service supply chain resilience to the COVID-19 outbreak: Lessons learned from the automobile and airline industries. Technological Forecasting \& Social Change $163,120447$.

Bleaney, M., and Greenaway, D. (2001). The Impact of Terms of Trade and Real Exchange Volatility on Investment and Growth in Sub-Saharan Africa. Journal of Development Economics, 65(2), 491-500.

Blundell, R., and Bond, S. (1998). Initial Conditions and Moment Restrictions in Dynamic Panel Data Models. Journal of Econometrics, 87(1), 115-143.

Bowen, A., Cochrane, S. and Fankhauser, S. (2012). Climate change, adaptation and economic growth. Climatic Change, 113, 95-106.

Bravo-Ortega, C., and Di Giovanni, J. (2006). Remoteness and Real Exchange Rate Volatility. IMF Economic Review, 53, 115-132.

Briguglio, L., Cordina, G., Farrugia, N., and Vella, S. (2009). Economic Vulnerability and Resilience: Concepts and Measurements. Oxford Development Studies, 37(3), 229-247.

Bristow, G., and Healy, A. (2018). Innovation and regional economic resilience: an exploratory analysis. The Annals of Regional Science, 60, 265-284.

Brun, J. F., Carrère, C., Guillaumont, P., and de Melo, J. (2005). Has Distance Died? Evidence from a Panel Gravity Model. World Bank Economic Review, 19(1), 99-120.

Caldera Sánchez, A. and Röhn, O. (2016). How do policies influence GDP tail risks?”, OECD Economics Department Working Papers ECO/WKP (2016) 63, OECD Publishing, Paris.

Calì, M. and TeVelde, D. (2011). Does Aid for Trade Really Improve Trade Performance? World Development, 39(5), 725-740.

Camanho da Costa Neto, N., and Romeu, R. (2011). Did export diversification soften the impact of the global financial crisis? IMF Working Paper WP/11/99. International Monetary Fund, Washington, D.C.

Canh, N. P., and Thanh, S.D. (2020). The Dynamics of Export Diversification, Economic Complexity and Economic Growth Cycles: Global Evidence. Foreign Trade Review, https://doi.org/10.1177/0015732520970441 
Cappelli, R., Montobbio, F., and Morrison, A. (2021). Unemployment resistance across EU regions: the role of technological and human capital. Journal of Evolutionary Economics, 31, 147178.

Cappelli, R., Montobbio, F., and Morrison, A. (2021). Unemployment resistance across EU regions: the role of technological and human capital. Journal of Evolutionary Economics, 31, 147178.

Chiah, M., and Zhong, A. (2020). Trading from home: The impact of COVID-19 on trading volume around the world. Finance Research Letters, 37, 101784.

Chinn, M. D. and Ito, H. (2006). What Matters for Financial Development? Capital Controls, Institutions, and Interactions. Journal of Development Economics, 81(1), 163-192.

Coe, D.T., Subramanian, A., and Tamirisa, N.T. (2002). The missing globalisation puzzle, IMF Working Paper WP/02/171. International Monetary Fund, Washington, D.C.

Coelli, F., Moxnes, A., and Ulltveit-Moe, K.H. (2016). Better, Faster, Stronger: Global Innovation and Trade Liberalization. The Review of Economics and Statistics, 1-42. https://doi.org/10.1162/rest a 00951

Contractor, F.J., and Mudambi, S.M. (2008). The influence of human capital investment on the exports of services and goods: An analysis of the top 25 services outsourcing countries. Management International Review, 48, 433-445.

Coveri, A., Cozza, C., Nascia, L., and Zanfei, A. (2020). Supply chain contagion and the role of industrial policy. Journal of Industrial and Business Economics, 47, 467-482.

Davies, R., Kozul-Wright, R., Banga, R., Capaldo, J., and Gallogly-Swan, K. (2021). Reforming the International Trading System for Recovery, Resilience and Inclusive Development. UNCTAD Research Paper No. 65 - UNCTAD/SER.RP/2021/8.

De Nicola, F., and Tan, S. W. (2017). Firms' export decisions: demand trumps financial shocks. Policy Research Working Paper Series 7953. The World Bank, Washington, D.C.

Deardorff, A. V. (2014). Local comparative advantage: Trade costs and the pattern of trade. International Journal of Economic Theory, 10(1), 9-35.

del Rosal, I. (2019). Export diversification and export performance by destination country. Bulletin of Economic Research, 71(1), 58-74.

Dennis, A., and Shepherd, B. (2011). Trade Facilitation and Export Diversification. The World Economy, 34(1), 101-122.

Di Caro, P., and Fratesi, U. (2018). Regional determinants of economic resilience. Annals of Regional Science, 60, 235-240.

Driscoll, J. C., and Kraay, A.C. (1998). Consistent Covariance Matrix Estimation with Spatially Dependent Panel Data. Review of Economics and Statistics, 80(4), 549-560. 
Eichengreen, B., and Leblang, D. (2003). Capital Account Liberalization and Growth: Was Mr. Mahathir Right?. International Journal of Finance and Economics, 8(3), 205-224.

Esfahani, H. S. and Ramirez, M. T. (2003). Institutions, Infrastructure, and Economic Growth. Journal of Development Economics, 70(2), 443-7.

Evenett, S., Fiorini, M., Fritz, J., Hoekman, B., Lukaszuk, P., Rocha, N., Ruta, M., Santi, P., and Shingal, A. (2020). Trade Policy Responses to the COVID-19 Pandemic Crisis. Evidence from a New Data Set. Policy Research Working Paper 9498, World Bank, Washington, D.C.

Farrugia, G., and Plutowski, R.W. (2021). Innovation Lessons From the COVID-19 Pandemic. Perspective and Controversy, 95(8), 1574-1577.

Feindouno, S., and Goujon, M. (2016). The retrospective economic vulnerability index, 2015 update. Working paper $n^{\circ} 147$, Fondation pour les Etudes et Recherches sur le Developpement InternationaL (FERDI), Clermont-Ferrand, France.

Feng, L., and Lin, C-Y. (2013). Financial shocks and exports. International Review of Economics \& Finance, 26, 39-55.

Funke, M., and Ruhwedel, R. (2001). Export variety and export performance: empirical evidence from East Asia. Journal of Asian Economics, 12, 493-505.

Funke, M., and Ruhwedel, R. (2002). Export variety and export performance: empirical evidence for the OECD Countries. Review of World Economics, 138, 97-114.

Gassebner, M., Keck, A., and Teh, R. (2010). Shaken, not stirred: the impact of disasters on international trade. Review of International Economics, 18(2), 351-368.

Gnan Al-Abri, A. (2013). Real exchange rate volatility, terms-of-trade shocks, and financial integration in primary-commodity exporting economies. Economics Letters, 120(1), 126-129.

Ghosh, A., and Ostry, J. (1994). Export Instability and the External Balance in Developing Countries. IMF Staff Papers 41(2), 214-35.

Gnangnon, S. K. (2019a). Has the WTO's Aid for Trade Initiative Delivered on Its Promise of Greater Mobilization of Development Aid in Favor of the Trade Sector in Developing Countries? International Trade Journal, 33(6), 519-541.

Gnangnon, S. K. (2019b). Aid for Trade and Recipient-Countries' Export Structure: Does Trade Policy Liberalization Matter? Arthaniti: Journal of Economic Theory and Practice, 18(1), 56-85.

Gnangnon, S. K. (2020). Aid for Trade flows and Real Exchange Rate Volatility in RecipientCountries. Journal of International Commerce, Economics and Policy, https://doi.org/10.1142/S1793993322500016

Gnangnon, S.K. (2021a). Effect of Productive Capacities on Economic Complexity: Do Aid for Trade flows Matter? Research Square, Preprints Paper, February 2021, (doi: 10.21203/rs.3.rs257879/v1) 
Gnangnon, S.K. (2021b). Productive Capacities, Economic Growth and Economic Growth Volatility in Developing Countries: Does Structural Economic Vulnerability Matter?. Preprints Paper, April 2021, 2021040491 (doi: 10.20944/preprints202104.0491.v1).

Gnangnon, S.K. (2021c). Effect of Productive Capacities on Economic Resilience in Developing Countries. Preprints Paper, May 2021, 2021050048 (doi: 10.20944/preprints202105.0048.v1).

Gnangnon, S.K. (2021d). Effect of Development Aid on Productive Capacities, ZBW - Leibniz Information Centre for Economics, Kiel, Hamburg.

Gnangnon, S.K. (2021e). Services export diversification and services export revenue stability: does trade openness matter?", International Trade, Politics and Development, Vol. ahead-of-print No. ahead-of-print. https://doi.org/10.1108/ITPD-04-2020-0012

Gradeva, K., and Martínez-Zarzoso, I. (2015). Are Trade Preferences more Effective than Aid in Supporting Exports? Evidence from the 'Everything But Arms' Preference Scheme. The World Economy, 39(8), 1146-1171.

Grossman, GM, and Helpman, E. (2015). Globalization and growth. American Economic Review, 105(5), 100-104.

Guillaumont, P. (2009). An Economic Vulnerability Index: Its Design and Use for International Development Policy. Oxford Development Studies, 37(3), 193-228.

Guillaumont, P. (2017). Vulnerability and Resilience: A Conceptual Framework Applied to Three Asian Countries - Bhutan, Maldives, and Nepal. ADB South Asia Working Paper No. 53, Asian Development Bank, Philippines.

Güneri, B., and Yalta, A. Y. (2020). Does economic complexity reduce output volatility in developing countries? Bulletin of Economic Research, https://doi.org/10.1111/boer.12257

Haddad, M., Lim, J. J., Pancaro, C., and Saborowski, C. (2013). Trade openness reduces growth volatility when countries are well diversified. Canadian Journal of Economics, 46(2), 765-790.

Hallegatte, S. (2014). Economic Resilience - Definition and Measurement. World Bank Policy Research Working Paper, WPS6852. The World Bank, Washington, D.C.

Hayakawa, K., and Mukunoki, H. (2021). The impact of COVID-19 on international trade: Evidence from the first shock. Journal of the Japanese and International Economies, 60, 101135.

Hendy, R., and Zaki, C. (2021). Trade facilitation and firms exports: Evidence from customs data. International Review of Economics \& Finance, 75, 197-209.

Hundt, C., and Holtermann, L. (2020). The role of national settings in the economic resilience of regions - Evidence from recessionary shocks in Europe from 1990 to 2014. Growth and Change, 51(1), 180-206.

Hwang, S., and Im, H. (2013). Financial shocks and trade finance: Evidence from Korea, Economics Letters, 120(1), 104-107. 
IMF (2021). World Economic Outlook: Managing Divergent Recoveries. International Monetary Fund, Washington, D.C., April 2021.

Iwanow, T., and Kirkpatrick, C. (2009). Trade facilitation and manufactured exports: Is Africa different?. World Development, 37, 1039-1050.

Jolles, M., Meyermans, E., and Vasicek, B. (2018). Determinants of economic resilience in the euro area: An empirical assessment of policy levers. Quarterly Report on the Euro Area (QREA), Directorate General Economic and Financial Affairs (DG ECFIN), European Commission, 17(3), $27-46$.

Ju, J., Wu, Yi, and Zeng, Li. (2010). The Impact of Trade Liberalization on the Trade Balance in Developing Countries. IMF Staff Papers, 57(2), 427-449.

Kadri, F., Birregah, B., and Châtelet, E. (2014). The Impact of Natural Disasters on Critical Infrastructures: A Domino Effect-based Study. Journal of Homeland Security and Emergency Management, 11(2), 217-241.

Khan, I.U., and Kalirajan, K. (2011). The impact of trade costs on exports: An empirical modelling. Economic Modelling, 28)3), 1341-1347.

Kinnan, C., and Townsend, R. (2012). Kinship and financial networks, formal financial access, and risk reduction. The American Economic Review: Papers \& Proceedings, 102(3), 289-293.

Kramarz, F., Martin, J., and Mejean, I. (2020). Volatility in the small and in the large: The lack of diversification in international trade. Journal of International Economics, 122, Article 103276.

Kristjánsdóttir, H. (2012). Exports from a remote developed region: analysed by an inverse hyperbolic sine transformation of the gravity model. The World Economy, 35(7), 953-966.

Labys, W., and Lord, M.J. (1990). Portfolio Optimization and the Design of Latin American Export Diversification Policies. Journal of Development Studies, 26(2), 260-77.

Lagravinese, R. (2015). Economic crisis and rising gaps North-South: Evidence from the Italian regions. Cambridge Journal of Regions, Economy and Society, 8(2), 331-342.

Li, C., and Lin, X. (2021). COVID-19 and trade: Simulated asymmetric loss. Journal of Asian Economics, 75, 101327.

Li, Y., and Zobel, C.W. (2020). Exploring supply chain network resilience in the presence of the ripple effect. International Journal of Production Economics, 228, 107693.

Love, J. (1983). Concentration, diversification and earnings instability: Some evidence on developing countries' exports of manufactures and primary products. World Development, 11(9), 787-793.

Maggioni, D., Lo Turco, A., and Gallegati, M. (2016). Does product complexity matter for firms' output volatility? Journal of Development Economics, 121, 94-109. 
Markusen, J. R., and Venables, A. J. (1999). Foreign direct investment as a catalyst for industrial development. European Economic Review, 43(2), 335-356.

Martin, R., and Sunley, P. (2015). On the notion of regional economic resilience: conceptualization and explanation, Journal of Economic Geography, 15(1), 1-42.

Martinez-Zarzoso, I., Nowak-Lehmann, F. and Rehwald, K. (2017). Is Aid for Trade Effective? A Panel Quantile Regression Approach. Review of Development Economics, 21(4), e175-e203

Marto, R., Papageorgiou, C., and Klyuev, V. (2018). Building resilience to natural disasters: An application to small developing states. Journal of Development Economics, 135, 574-586.

Massell, B. F. (1964). Export Concentration and Fluctuations in Export Earnings: A Cross-Section Analysis. The American Economic Review, 54(2), Part 1, 47-63.

Mayunga, J.S. (2007). Understanding and Applying the Concept of Community Disaster Resilience: A Capital-Based Approach', draft working paper prepared for the summer academy, Megacities as Hotspots of Risk: Social Vulnerability and Resilience Building, Munich, Germany, 22-28 July 2007.

Meyer, B., Mösle, S., and Windisch, M. (2020). Lessons from past disruptions to global value chains. UNIDO Industrial Analytics Platform, May 2020. Retrieved at. https://iap.unido.org/articles/lessons-past-disruptions-global-value-chains

Miller, T., Kim, A. B., Roberts, J.M., and Tyrrell, P. (2021). 2021 Index of Economic Freedom, Institute for Economic Freedom, The Heritage Foundation, Washington, DC. See online: https://www.heritage.org/index/pdf/2021/book/index_2021.pdf

Miranda-Pinto, J. (2021). Production network structure, service share, and aggregate volatility. Review of Economic Dynamics, 39, 146-173.

Miroudot, S. (2020). Reshaping the policy debate on the implications of COVID-19 for global supply chains. Journal of International Business Policy, 3, 430-442.

Montalbano, P. (2011). Trade Openness and Developing Countries' Vulnerability: Concepts, Misconceptions, and Directions for Research. World Development, 39(9), 1489-1502.

Munch, J.R., and Skaksen, J. R. (2008). Human capital and wages in exporting firms. Journal of International Economics, 75(2), 363-372.

National Board of Trade Sweden (2020). Improving Economic Resilience Through Trade - should we rely on our own supply? 51 pages. The National Board of Trade Sweden, Stockholm, Sweden. Retrieved at: https://www.wita.org/atp-research/improving-economic-resilience/

Nordhagen, S., Igbeka, U., Rowlands, H., Shine, R. S., Heneghan, E., and Tench, J. (2021). COVID-19 and small enterprises in the food supply chain: Early impacts and implications for longer-term food system resilience in low-and middle-income countries. World Development, 141, 105405. 
Obstfeld, M. (1994). Risk-taking, global diversification and growth. American Economic Review, 84(5), 1310-1329.

OECD (2017). OECD G20 Policy Paper on Economic Resilience and Structural Policies; OECD: Paris, France.

OECD (2020), Development Co-operation Report 2020: Learning from Crises, Building Resilience, OECD Publishing, Paris, https://doi.org/10.1787/f6d42aa5-en

OECD (2021). Fostering economic resilience in a world of open and integrated markets - Risks, vulnerabilities and areas for policy action. Report prepared for the 2021. UK Presidency of the G7.

Oh, C. H., and Reuveny, R. (2010). Climatic natural disasters, political risk, and international trade. Global Environmental Change, 20(2), 243-254.

Olarreaga, M. (2016). Trade, Infrastructure and Development. FERDI Working Paper Development Policies $n^{\circ} 177$. Fondation pour les Etudes et Recherches sur le Développement International (FERDI), Clermont-Ferrand, France.

Osakwe, P.N., Santos-Paulino, A.U., and Dogan, B. (2018). Trade dependence, liberalization, and exports diversification in developing countries. Journal of African Trade, 5(1-2), 19-34.

Paudel, J., and Ryu, H. (2018). Natural disasters and human capital: The case of Nepal's earthquake. World Development, 111, 1-12.

Paunov, C., and Planes-Satorra, S. (2021). Science, technology and innovation in the time of COVID-19. OECD Science, Technology and Industry Policy Papers, February 2021, No. 99. OECD, Paris.

Paunov, C., and Rollo, V. (2016). Has the internet fostered inclusive innovation in the Developing World? World Development, 78, 587-609.

Portugal-Perez, A., and Wilson, J.S. (2012). Export Performance and Trade Facilitation Reform: Hard and Soft Infrastructure. World Development, 40(7), 1295-1307.

Rodrik, D. (1999). Where Did All the Growth Go? External Shocks, Social Conflict, and Growth Collapses. Journal of Economic Growth, 4(4), 385-412.

Rose, A., Wei, D., and Paul, D. (2018). Economic consequences of and resilience to a disruption of petroleum trade: The role of seaports in U.S. energy security. Energy Policy, 115, 584-615.

Saltarelli, F., Cimini, V., Tacchella, A., Zaccaria, A., and Cristelli, M. (2020). Is Export a Probe for Domestic Production? Frontiers in Physics, 8, 180, doi: 10.3389/fphy.2020.00180

Santos-Paulino, A. U. (2007). Aid and Trade Sustainability under Liberalisation in Least Developed Countries. The World Economy, 30(6), 972-998.

Schmukler, S. and Vesperoni, E. (2006). Financial Globalization and Debt Maturity in Emerging Economies. Journal of Development Economics, 79(1), 183-207. 
Seidu, D., and Maciej, D. (2020). Barriers to Competition in Product Market Regulation: New Insights on Emerging Market and Developing Economies. World Bank, Washington, D.C.

Sepehrdoust, H., Davarikish, R., and Setarehie, M. (2019). The knowledge-based products and economic complexity in developing countries. Heliyon, 5(12), e02979.

Shepherd, B. (2010). Geographical Diversification of Developing Country Exports. World Development, 38(9), 1217-1228.

Somville, V., and Vandewalle, L. (2019). Access to Banking, Savings and Consumption Smoothing in Rural India. Graduate Institute of International and Development Studies Working Paper No. HEIDWP09-2019, Geneva Switzerland.

Sondermann, D. (2018). Towards more resilient economies: The role of well-functioning economic structures. Journal of Policy Modeling, 40(1), 97-117.

Spatareanu, M., Manole, V., and Kabiri, A. (2018). Exports and bank shocks: Evidence from matched firm-bank data. Structural Change and Economic Dynamics, 47, 46-56.

Stulz, R. (1999). Globalization, Corporate Finance and the Cost of Capital. Journal of Applied Corporate Finance, 12(3), 8-25.

Taghizadeh-Hesar, F., Sarker, T., Yoshino, N., Mortha, A., and Vo, X.V. (2021). Quality infrastructure and natural disaster resiliency: A panel analysis of Asia and the Pacific. Economic Analysis and Policy, 60, 394-406.

Tambo, J.A., and Wünscher, T. (2017). Enhancing resilience to climate shocks through farmer innovation: evidence from northern Ghana. Regional Environmental Change, 17, 1505-1514.

UNCTAD (2006). The Least Developed Countries Report 2006: Developing Productive Capacities. United Nations publication. Sales No. E.06.II.D.9., New York and Geneva.

UNCTAD (2020). The Least Developed Countries Report 2020: Productive Capacities for the New Decade. United Nations publication. Sales No. E.21.II.D.2 New York and Geneva.

United Nations (2016). Global Sustainable Development Report 2016. Department of Economic and Social Affairs, New York.

Vannoorenberghe, G., Wang, Z., and Yu, Z. (2016). Volatility and diversification of exports: Firmlevel theory and evidence. European Economic Review, 89, 216-247.

Vijil, M. and Wagner, L. (2012). Does Aid for Trade Enhance Export Performance? Investigating on the Infrastructure Channel. World Economy 35 (7), 838-868.

Vijil, M., and Wagner, L. (2012). Does Aid for Trade Enhance Export Performance? Investigating the Infrastructure Channel. The World Economy, 37(7), 838-868.

Wang, R., Tan, J., and Yao, S. (2021). Are natural resources a blessing or a curse for economic development? The importance of energy innovations. Resources Policy, 72, 102042. 
Woolliscroft, J.O. (2021). Innovation in Response to the COVID-19 Pandemic Crisis. Academic Medicine, 95(8), 1140-1142.

WTO (World Trade Organization) (2005). Ministerial Declaration on Doha Work Programme', WT/MIN(05)/DEC, Adopted on 18 December 2005 at the Sixth Session of Trade Ministers Conference. Ministerial Conference, Hong Kong, China, December 13-18.

Wu, X., and Khazin, B.P. (2020). Patent-related actions taken in WTO members in response to the COVID-19 pandemic. WTO Staff Working Paper ERSD-2020-12. World Trade Organization, Geneva, Switzerland.

Xu, A., and Kouwoaye, A.R. (2019). How do natural disasters affect services trade? WTO Staff Working Paper ERSD-2019-12. World Trade Organization, Geneva, Switzerland.

Zeev, N.B., and Ifergane, T. (2021). Firing restrictions and economic resilience: Protect and survive? Review of Economic Dynamics, Available online 8 February 2021. In Press, Corrected Proof - https://doi.org/10.1016/j.red.2021.01.003 